\title{
Hydrology, river regimes and sediment yield
}

Link to publication record in Manchester Research Explorer

\section{Citation for published version (APA):}

Woodward, J. C., Thornes, J. B., \& Lopez-Bermudez, F. (2009). Hydrology, river regimes and sediment yield. In The Physical Geography of the Mediterranean (1st ed., pp. 229-253). Oxford University Press.

\section{Published in:}

The Physical Geography of the Mediterranean

\section{Citing this paper}

Please note that where the full-text provided on Manchester Research Explorer is the Author Accepted Manuscript or Proof version this may differ from the final Published version. If citing, it is advised that you check and use the publisher's definitive version.

\section{General rights}

Copyright and moral rights for the publications made accessible in the Research Explorer are retained by the authors and/or other copyright owners and it is a condition of accessing publications that users recognise and abide by the legal requirements associated with these rights.

\section{Takedown policy}

If you believe that this document breaches copyright please refer to the University of Manchester's Takedown Procedures [http://man.ac.uk/04Y6Bo] or contact uml.scholarlycommunications@manchester.ac.uk providing relevant details, so we can investigate your claim.

\section{OPEN ACCESS}




\title{
Hydrology, River Regimes, and Sediment Yield
}

\author{
John Thornes, Francisco López-Bermúdez, \\ and Jamie Woodward
}

\section{Introduction}

In comparison to the rest of Europe, Africa, and Asia, most rivers arising and flowing within the Mediterranean watershed typically drain small catchments with mountainous headwaters (Figure 8.1). The hydrology of Mediterranean catchments is strongly influenced by the seasonal distribution of precipitation, catchment geology, vegetation type and extent, and the geomorphology of the slope and channel systems. It is important to appreciate, as the preceding chapters have shown, that the area draining to the Mediterranean Sea is large and enormously variable in terms of the key controls on catchment hydrology outlined above, and it is therefore not possible to define, in hydrological terms, a strict single Mediterranean river type. However, river regimes across the basin do have a marked seasonality that is largely controlled by the climate system (Chapter 3) and, in most basins, the dominant flows occur in winter-but autumn and spring runoff is also important in many areas. These patterns reflect the general water balance of the basin as a whole, but there are key geographical patterns in catchment hydrology and sediment yield and a marked contrast is evident between the more humid north and the semi-arid south and east (Struglia et al. 2004; Chapter 21). Also, because of the long history of vegetation and hillslope modification by human activity and the more recent and widespread implementation of water resource management projects, there are almost no natural river regimes in the Mediterranean region, especially in the middle and lower reaches of river catchments (Cudennec et al. 2007).
Runoff generation on hillslopes in the Mediterranean is very closely related to rainfall intensities and land surface properties as discussed in Chapter 6. While this is probably true of most catchments, runoff generation in the Mediterranean is very sensitive to vegetation cover because of the seasonal dynamics of rainfall and the role played by extreme events. The cumulative effect of these characteristics is a specific set of management problems and restoration issues and, although these are rather different in the various socio-political regimes of the region, it can be argued that they are in many ways unique to Mediterranean catchments.

\section{The Water Balance and Mediterranean River Regimes}

\section{The Annual Water Budget}

The broad water balance for the Mediterranean basin as a whole is summarized in Figure 8.2 which is based on the work of Jean Margat (Chapter 21) and published in Grenon and Batisse (1989). This shows mean values for annual water fluxes in the region in $\mathrm{km}^{3}$ (1 cubic kilometre $=1$ billion $\mathrm{m}^{3}$ ). It is important to realize that these values will vary from year to year and they mask very significant spatial variations in catchment hydrology as we explain below. Nonetheless Figure 8.2 provides a very useful illustration of the magnitude of the annual water exchanges in the region between the atmosphere, the terrestrial catchment systems, and the Mediterranean Sea itself. Annual precipitation input to the Mediterranean 'catchment' is of the order of 


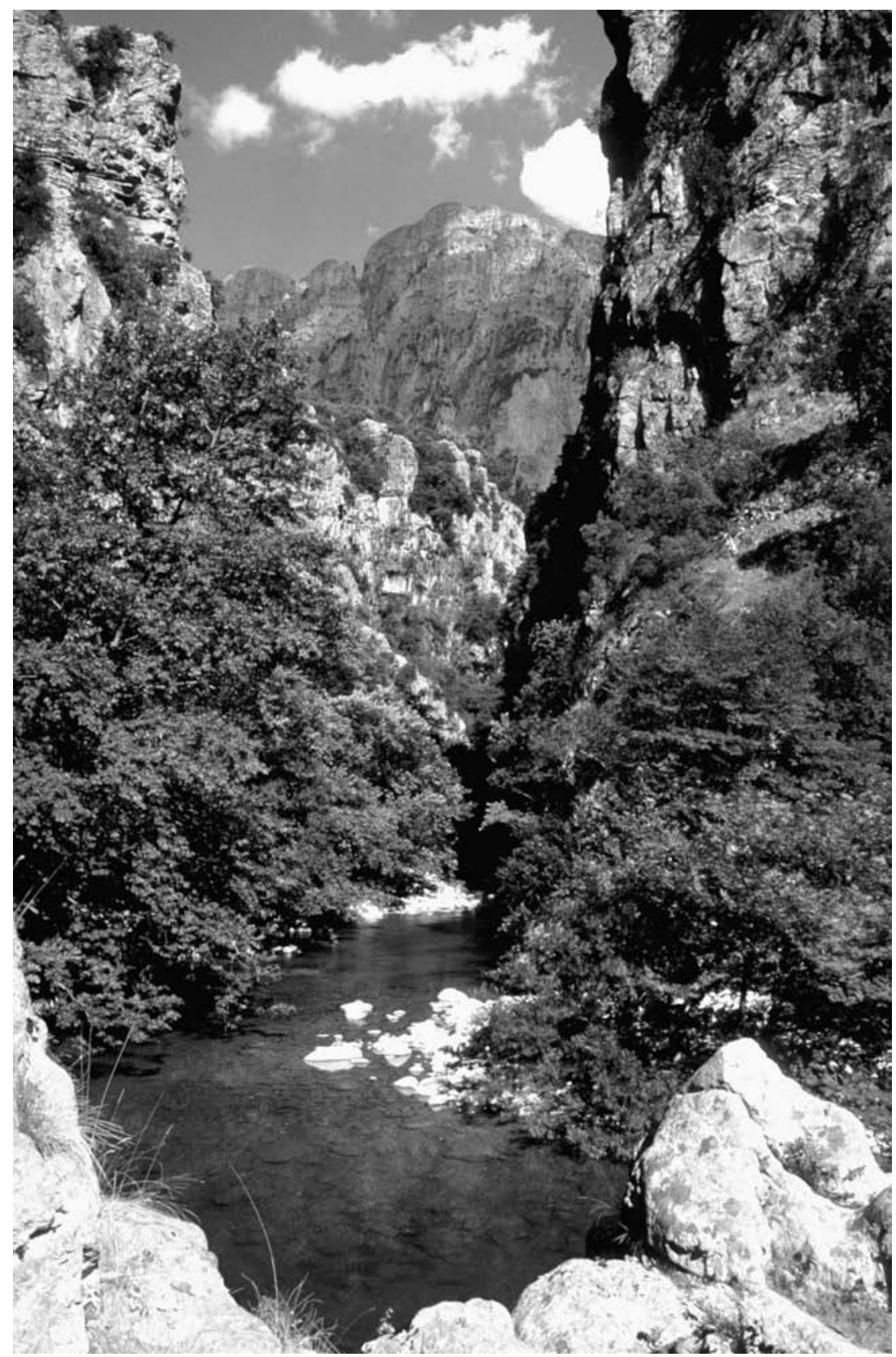

Fig. 8.1. An upland river catchment in the mountains of north-west Greece (photo: Jamie Woodward).
$1,070 \mathrm{~km}^{3}$ each year with total evaporation losses of around $685 \mathrm{~km}^{3}$ per year. Taking into account contributions from larger river systems (such as the Nile and the Rhône that drain areas beyond the Mediterranean region), groundwater flows, and human water uses, this budget gives an annual terrestrial water yield to the Mediterranean Sea of about $477 \mathrm{~km}^{3}$. This component of the water balance in relation to the annual exchange of water between the Mediterranean Sea and the Atlantic Ocean is discussed in Chapter 2 and all components of 


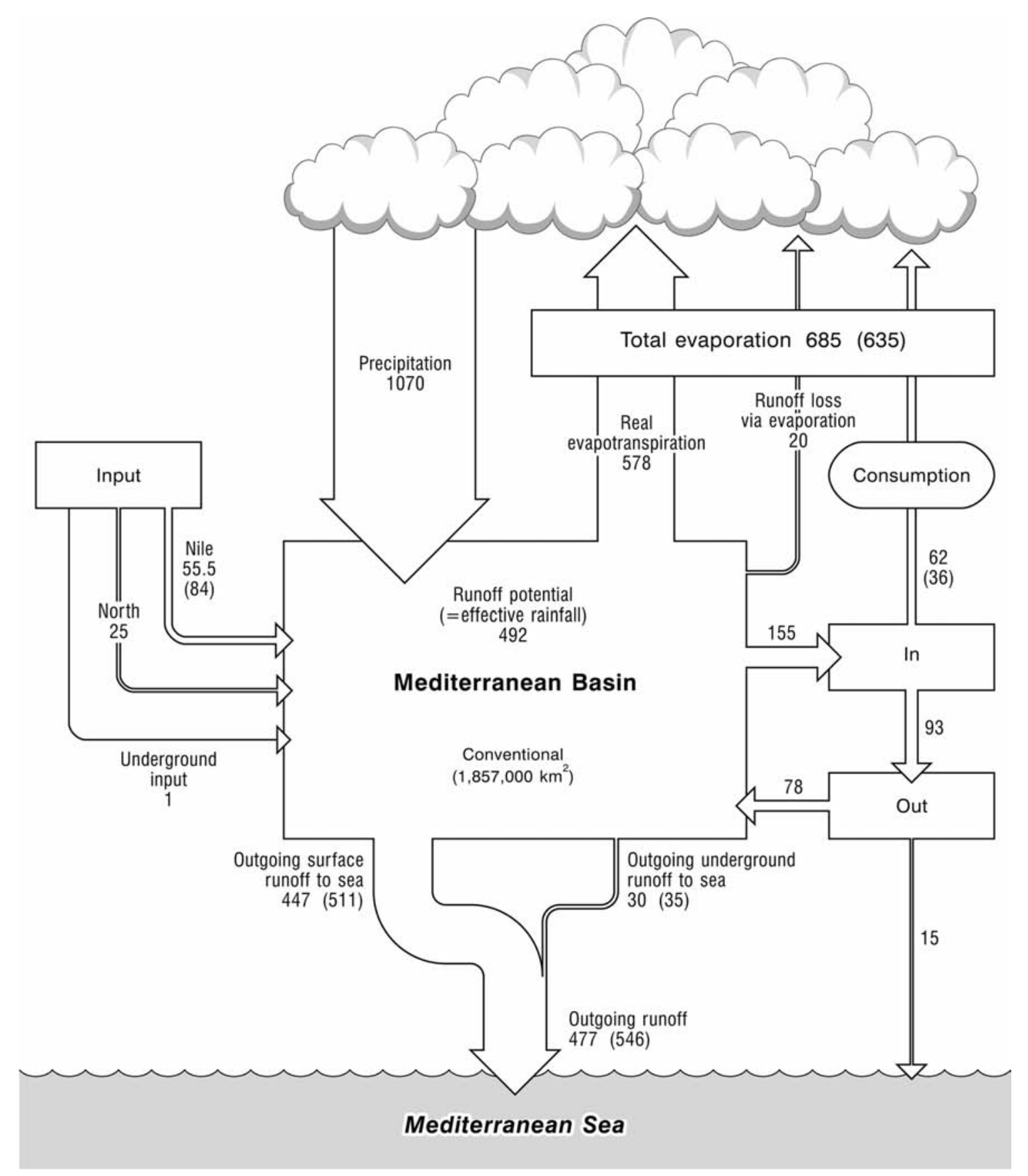

Fig. 8.2. The water balance of the Mediterranean region showing the major fluxes (in $\mathrm{km}^{3}$ per year) between the main components of the hydrological cycle (modified from Grenon and Batisse 1989, and based on the work of Jean Margat). Values in brackets represent earlier estimates of these components. 


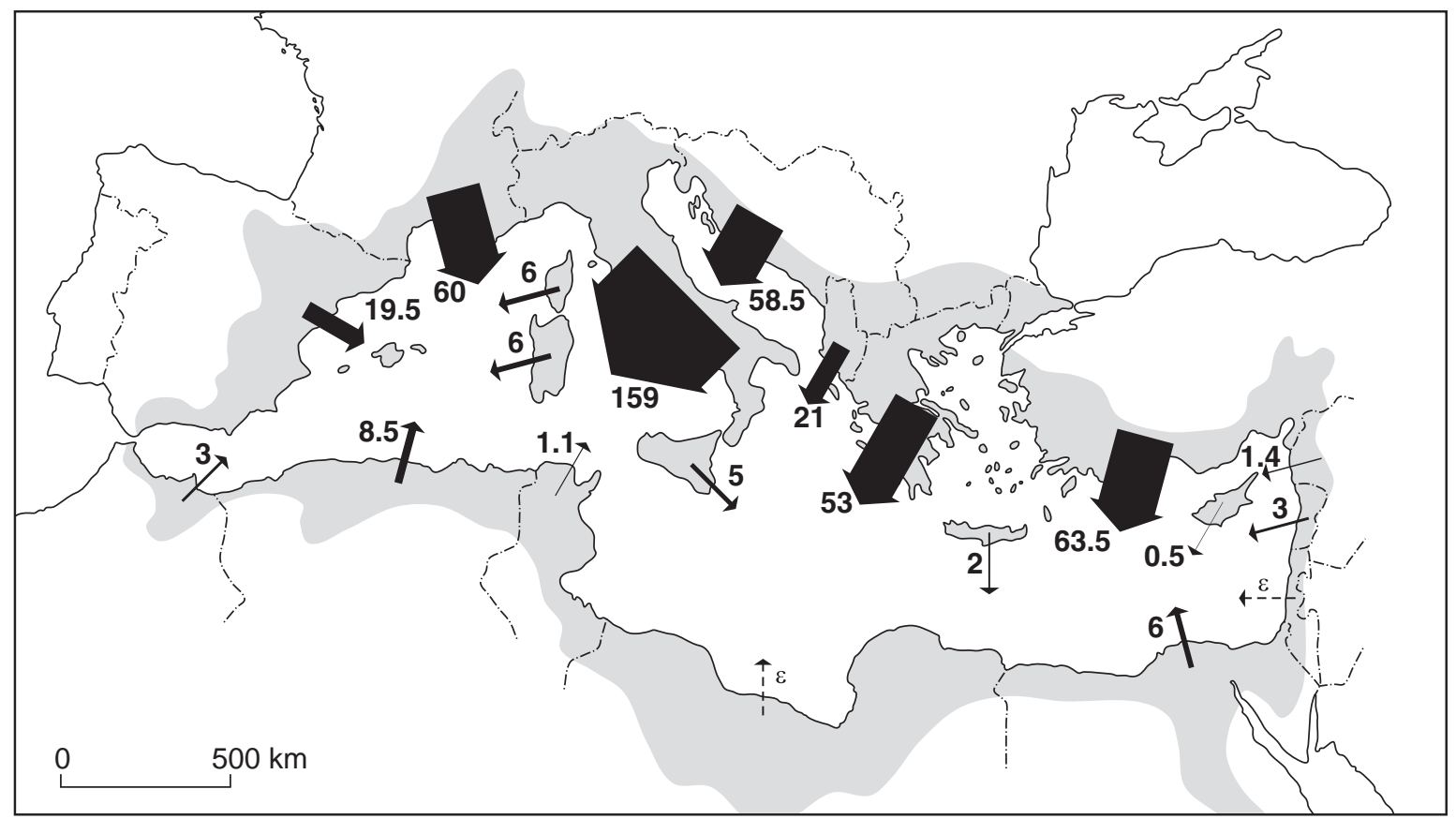

Fig. 8.3. Total annual runoff from river basins (shaded area) in each country bordering the Mediterranean Sea. The runoff values are given in $\mathrm{km}^{3}$ per year. The runoff volumes from river catchments in Libya, Israel, and Palestine (shown as $\epsilon$ ) are negligible at this scale. The value given here for the Nile reflects the impact of the High Aswan Dam (modified from Grenon and Batisse 1989).

this water budget are expected to change significantly in coming decades given the predictions for climate change in the region presented in Chapter 3.

An examination of annual catchment runoff to the Mediterranean Sea on a country by country basis shows large spatial variations in river discharge. Figure 8.3 shows the average annual flows $\left(\mathrm{km}^{3}\right)$ as they were in 1985 and reported by Grenon and Batisse (1989) as part of the Blue Plan initiative. The main feature here is the marked contrast between the perennially flowing rivers on the north side of the basin and the very small contributions made by the strongly seasonal and ephemeral river catchments on the south side of the basin and in the Levant. In fact, the total contribution from river systems in Morocco, Algeria, and Tunisia $\left(12.6 \mathrm{~km}^{3}\right.$ per year) is almost matched by the combined runoff from just Corsica and Sardinia. Fluvial runoff to the Mediterranean Sea is dominated by river systems in Italy, Turkey, France, Greece, and the countries of the former Yugoslavia. Flows from the Nile have fallen dramatically since the construction of the High Aswan Dam and major irrigation schemes (Woodward et al. 2007).
The total annual flow of Mediterranean rivers depends on the annual water balance partition in their catchments. This has been studied and modelled by Eagleson (1978) and is depicted in Figure 8.4. This shows how annual rainfall input is divided into evapotranspiration loss from soil moisture, seepage loss to groundwater, and rainfall excess (that becomes river runoff). As mean annual precipitation increases from left to right along the horizontal axis, the rainfall excess increases, as shown in the shaded area. Thus the vertical line (1) represents the water-balance of rivers from the semi-arid and arid parts of the Mediterranean, such as those of south-east Spain, North Africa, and Israel. Vertical line (2) is the lower boundary of the sub-humid water balance regimes, found on the northern edges of the Mediterranean basin where rivers have sufficient water to flow the year round, and the soil moisture is sufficient to support a 'good' ground cover of vegetation. Finally, line (3) represents the 'humid' Mediterranean regimes of rivers with wooded mountain catchments (Chapters 3 and 7) and, of course, there are distinctive hydrological balances for special cases such as wetland systems (Chapter 9) and karst landscapes (Chapter 10). 


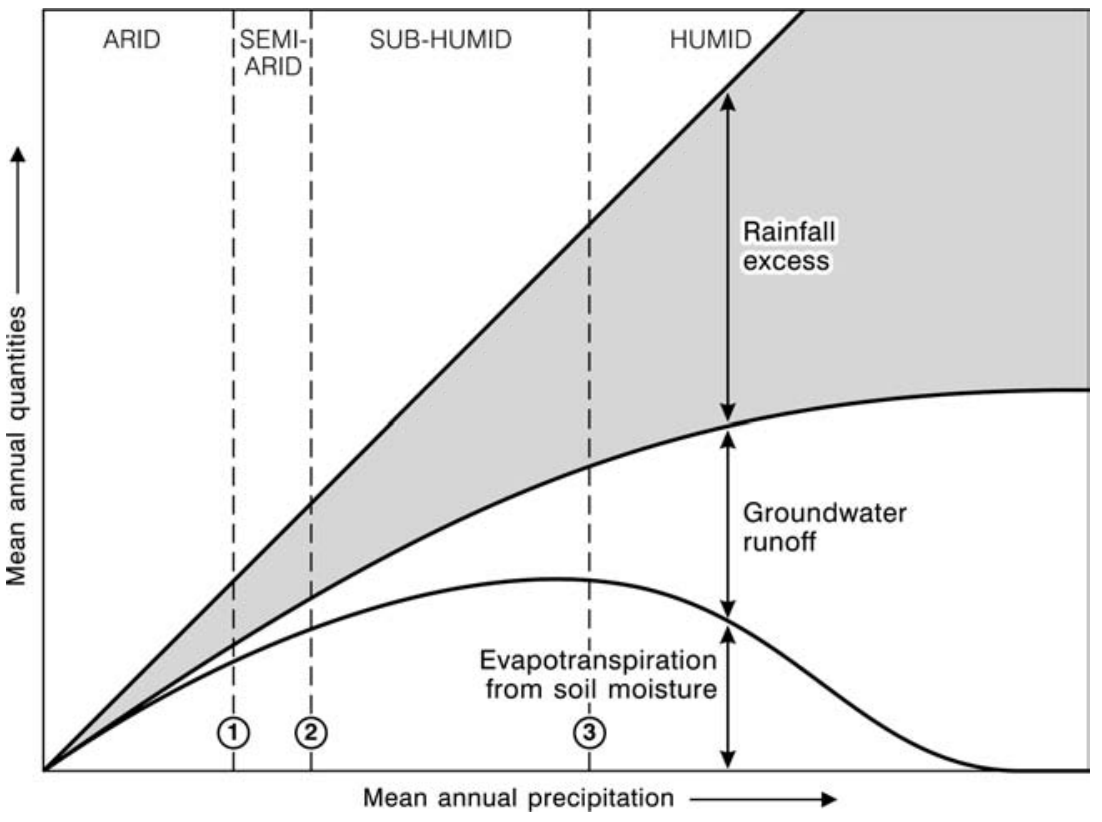

Fig. 8.4. Eagleson's decomposition of the annual water balance for catchments in different climatic settings. The shaded area is the 'rainfall excess' or the runoff to rivers. See text for further explanation (modified from Eagleson 1978). The groundwater runoff component is especially important in many Mediterranean catchments because of the widespread occurrence and thickness of limestone rocks (Chapter 10).

\section{Seasonal Distribution of River Flows}

Although all Mediterranean rivers have flows that have been greatly affected by human activity, the monthly pattern of flows or river regimes still reflects the broadly biophysical controls of climate and to a lesser extent groundwater storage. These climatic effects produce the major spatial distributions of vegetation types (Chapter 7) which combine to form key controls on land degradation as discussed in Chapter 20.

The seasonal distribution of river flows is controlled mainly by the seasonal distribution of rainfall as broadly shown in Figure 8.5. This diagram also provides an approximation of the range of river regime types across the Mediterranean region. The great allogenic rivers such as the Rhône and the Nile have headwaters outside the Mediterranean winter rainfall regime and have hybrid regimes and the Rhône is considered in more detail below. Typically the Mediterranean has rains in winter and autumn (Chapter 3) with the middle and lower reaches of many rivers being dry in the summer (Figure 8.6). This is characteristic of much of the Maghreb, the Levant, southern Greece, southern Italy, the very south-east and south of the Iberian Peninsula and most of Portugal. Most of the Iberian Peninsula, Italy, and the western parts of the Balkan Peninsula also receive significant autumn rains. Only the continental parts of the Balkan states and Macedonia have rainfall all year round. Monthly flow series for eight river gauging stations across the Mediterranean region (and one in the headwaters of the Rhône) are given in Figure 8.7. The histograms show the range of river regimes evident in the Mediterranean moving clockwise (a) to (i) around the basin (Figure 8.5) and include river systems in France, Italy, Albania, Turkey, Cyprus, Israel, Algeria, and Morocco. All the stations (b) to (i) show a marked summer decrease in river flows with the channel bed of the Vasilikos River $\left(151 \mathrm{~km}^{2}\right)$ in Cyprus drying out completely for five months from July to November. The flow data for the rivers in the east and south of the Mediterranean (e) to (i) highlight the importance of winter and spring precipitation in these catchments.

The Rhône at Chancy, on the French-Swiss border, has a mean annual discharge of $342 \mathrm{~m}^{3} \mathrm{~s}^{-1}$. The minimum and peak recorded flows at this station in the period January 1965 to December 1982 were 134 and $740 \mathrm{~m}^{3} \mathrm{~s}^{-1}$ respectively. This regime reflects the essentially Alpine character of the headwaters, with a strong spring and summer snowmelt. By the time the river reaches Beaucaire in the Garrigue, the Mediterranean regime is already evident. The catchment area here is almost $100,000 \mathrm{~km}^{2}$, about nine times that at Chancy. The mean discharge is $>1,600 \mathrm{~m}^{3} \mathrm{~s}^{-1}$ with minimum and maximum flows of 420 and $5,077 \mathrm{~m}^{3} \mathrm{~s}^{-1}$ respectively. The strong dip 


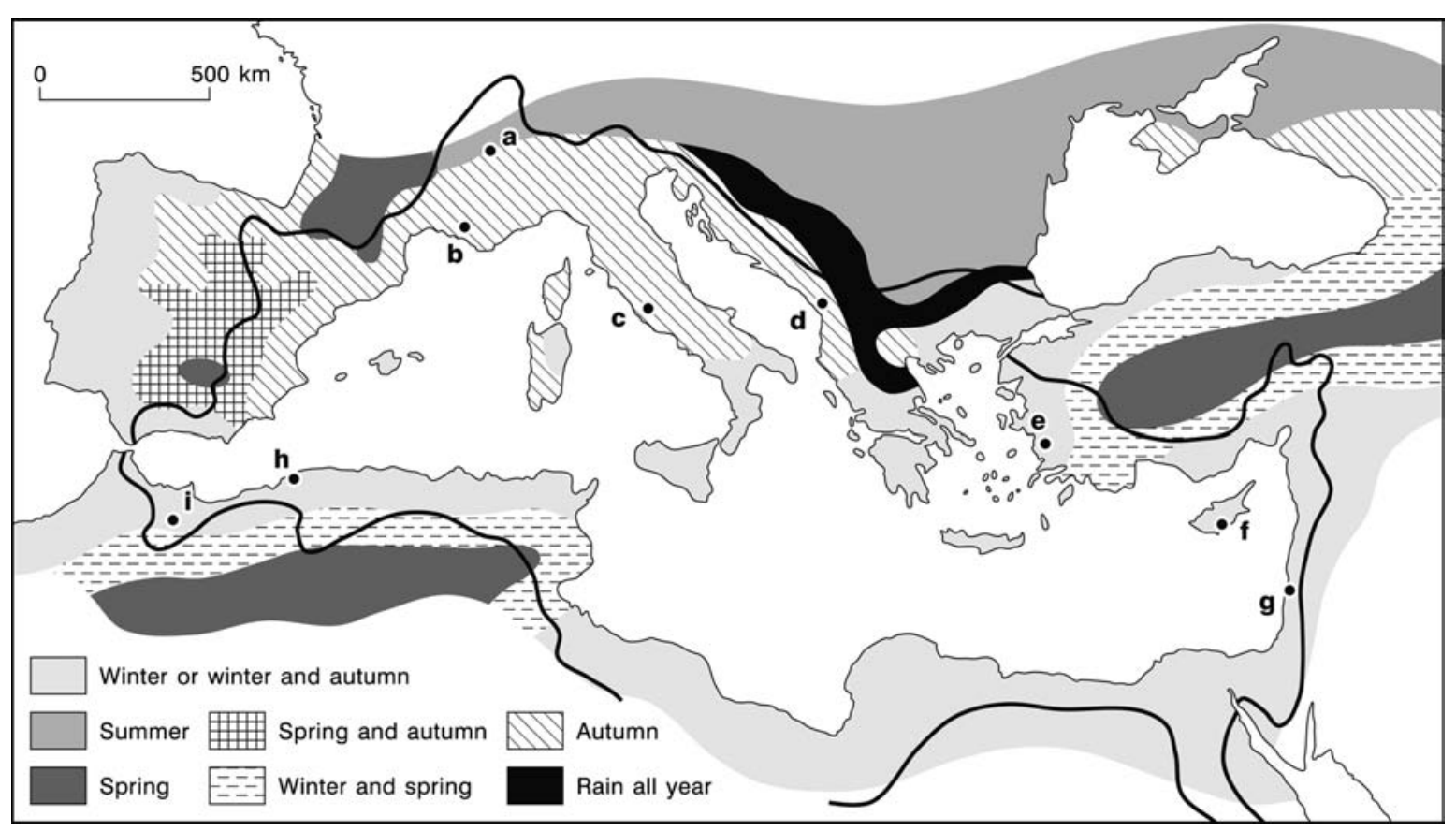

Fig. 8.5. Rainfall regimes in the Mediterranean region (modified from Huttary 1955). The solid line is the watershed of rivers that drain to the Mediterranean Sea. The letters (a to i) mark the locations of the gauging stations in Figure 8.7.

in the summer and early autumn months (July to October) is quite characteristic of the Mediterranean regime. Snowmelt makes an important contribution to many headwater river systems in the Mediterranean region-especially where the mountains rise above 2,000 $\mathrm{m}$ (Chapter 12). The regime for Wadi Moulouya in Morocco — at the Dar el Caid station-shows a more pronounced Mediterranean regime. Here the annual mean discharge is $20 \mathrm{~m}^{3} \mathrm{~s}^{-1}$ with minimum and maximum peak flows of 0 and $327 \mathrm{~m}^{3} \mathrm{~s}^{-1}$ respectively. August has the lowest average flow $\left(3.6 \mathrm{~m}^{3} \mathrm{~s}^{-1}\right)$ and April, the maximum, showing the spring rainfall effect (Figure 8.7). The catchment of the Wadi Moulouya at Dar el Caid $\left(24,422 \mathrm{~km}^{2}\right)$ is similar in size to the Menderes River at Soke $\left(23,889 \mathrm{~km}^{2}\right)$ in Turkey yet, due to the greater aridity of the local climate, its mean annual discharge is only about one fifth of the Menderes (Figure 8.7).

For large parts of the semi-arid Mediterranean, channels may be without flow for most of the summer but commonly restarting with the onset of autumn storms. Surface channel flows in these rivers normally cease in early May, though flow will often continue beneath the gravel beds and may be used for irrigation throughout the summer months. Many channels are truly ephemeral and convey flows only during major storm events (Cudennec et al. 2007)). In flash floods, water drains into the channel beds so the flows may only be evident in upland bedrock reaches and then disappear in the middle and downstream reaches where the channels are formed in thick coarse-grained gravely sediments (Thornes 1977; Butcher and Thornes 1978; Shannon et al. 2002). A key problem in many parts of the semiarid Mediterranean is the absence of reliable, long-term records of river flows.

\section{Human Modification of Mediterranean Catchment Hydrology}

The human history of the Mediterranean lands has been strongly moulded by its rivers (Lewin et al. 1995; Grove and Rackham 2003; Chapter 11) and among all the natural ecosystems, rivers and floodplains are the most intensively used by Mediterranean people. The floodplains have formed important corridors for the migration of plants, animals, and people and have also provided some of the most fertile alluvial soils in the 


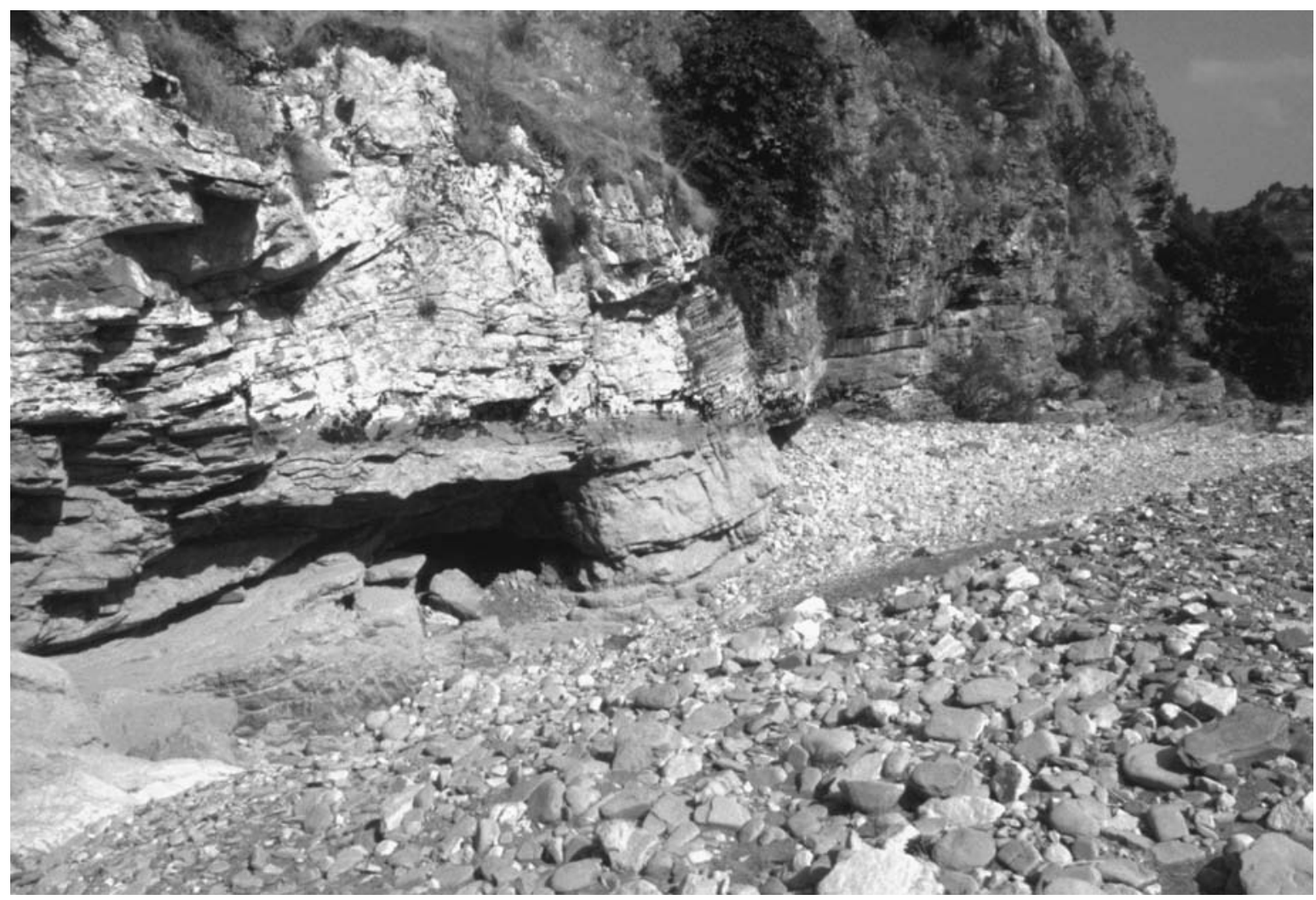

Fig. 8.6. The seasonally dry gravel-bed channel of the Voidomatis River upstream of the Vikos Gorge in north-west Greece (photo: Jamie Woodward). Note the high flow stage marks on the bedrock wall.

world, on which intensive irrigated agriculture has been established. Around them, complex legal systems for their use have developed.

As in other parts of the world, the human modification of river flows and channels has taken place both directly and indirectly. Indirect changes are those which change runoff generation and sediment supply at the basin scale-mainly through changes in land use. Direct changes are those which alter the flow regimes, sediment stores, and planform of the channel, usually by engineering works related to water resource development and flood protection or alluvial gravel extraction (e.g. Christopoulos 1998; Nicholas et al. 1999; Kapsimalis et al. 2005) (Chapter 11). What sets the Mediterranean region apart from other areas of the world, however, is the long history and widespread occurrence of both direct and indirect modifications to catchment hydrology and river channel systems (VitaFinzi 1978; Macklin et al. 1995).

\section{Indirect Changes to Catchment Systems}

\section{Vegetation Cover and Runoff Dynamics}

Elwell and Stocking (1976) showed that runoff from experimental plots was reduced as the vegetation cover was increased and the curve is exponential (Figure 8.8). On the horizontal axis is the percentage vegetation cover in plan view. On the vertical axis is the amount of runoff as a percentage of bare soil. This parameter is the result of many complex factors, as discussed later in this chapter, most prominently rainfall intensity, basin morphology, and soil characteristics, such as infiltration capacity and crusting. These experiments explain the earlier discoveries of American workers and the speculations of the ancient Greeks (Grove and Rackham 2003) and have been reconfirmed in many studies since, in 
(a) Rhône at Chancy, Switzerland

Catchment $=10,299 \mathrm{~km}^{2}$

Mean discharge $=341.61 \mathrm{~m}^{3} \mathrm{~s}^{-1}$

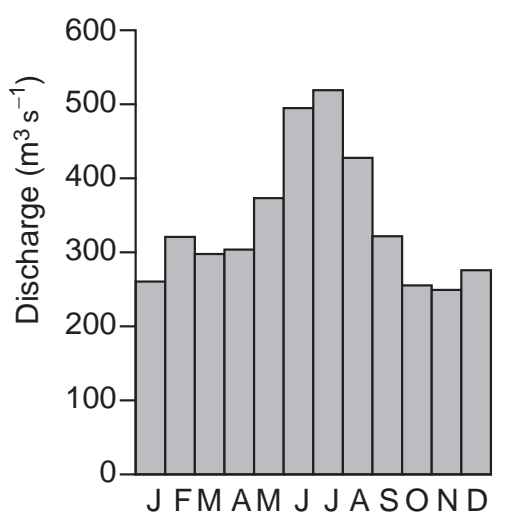

(d) Drin at Kalimash, Albania

Catchment $=12,368 \mathrm{~km}^{2}$

Mean discharge $=219.43 \mathrm{~m}^{3} \mathrm{~s}^{-1}$

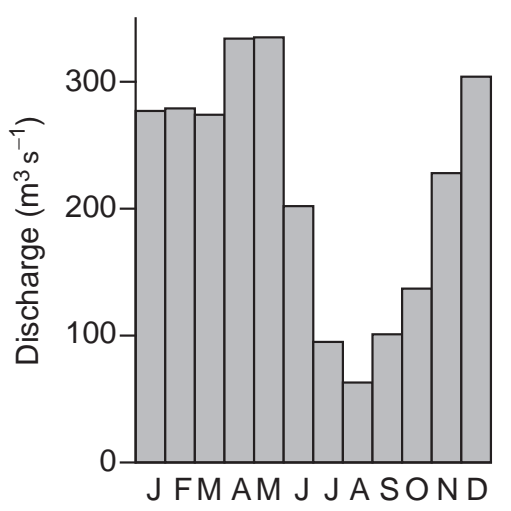

(g) Jordan at Obstacle Bridge, Israel

Catchment $=1,376 \mathrm{~km}^{2}$ Mean discharge $=18.05 \mathrm{~m}^{3} \mathrm{~s}^{-1}$

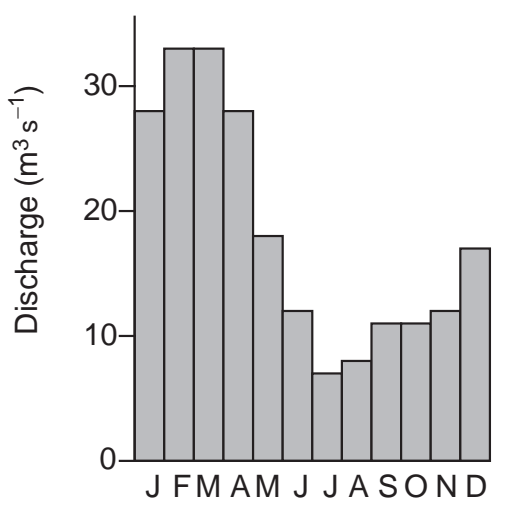

(b) Rhône at Beaucaire, France Catchment $=95,590 \mathrm{~km}^{2}$ Mean discharge $=1,694.95 \mathrm{~m}^{3} \mathrm{~s}^{-1}$

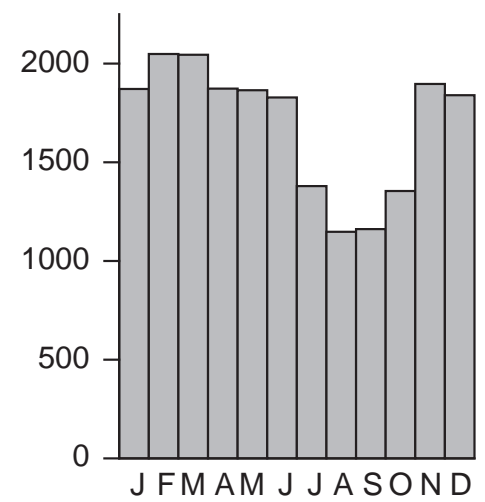

(e) Menderes at Soke, Turkey Catchment $=23,889 \mathrm{~km}^{2}$ Mean discharge $=101.24 \mathrm{~m}^{3} \mathrm{~s}^{-1}$ 250

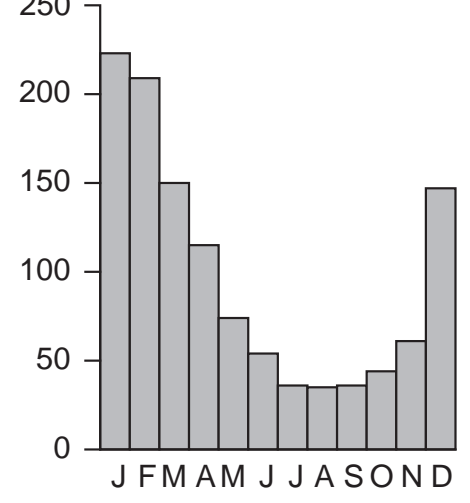

(h) Cheliff at Sidi Belatar, Algeria

Catchment $=43,750 \mathrm{~km}^{2}$
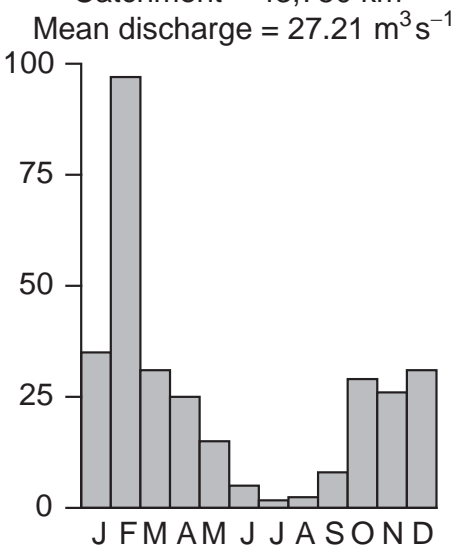

(c) Tiber at Rome, Italy

Catchment $=16,545 \mathrm{~km}^{2}$ Mean discharge $=231.13 \mathrm{~m}^{3} \mathrm{~s}^{-1}$

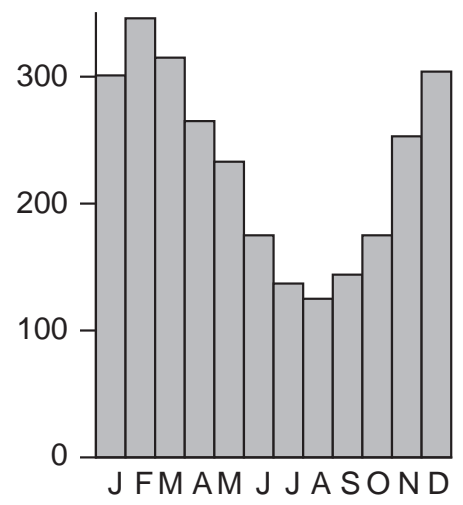

(f) Vasilikos at Zyyi, Cyprus Catchment $=151 \mathrm{~km}^{2}$ Mean discharge $=0.16 \mathrm{~m}^{3} \mathrm{~s}^{-1}$ 0.87

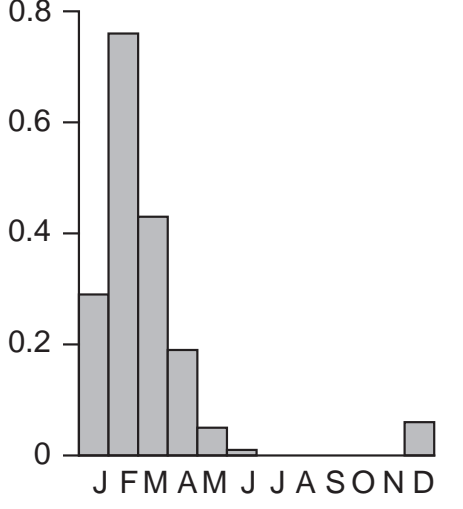

(i) Moulouya at Dar el Caid, Morocco

Catchment $=24,422 \mathrm{~km}^{2}$ Mean discharge $=21.15 \mathrm{~m}^{3} \mathrm{~s}^{-1}$

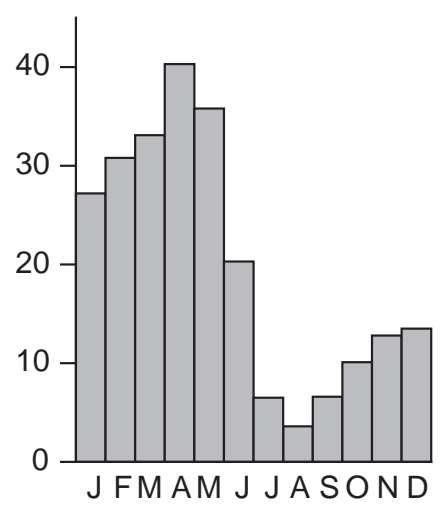

Fig. 8.7. Average monthly flows for rivers around the Mediterranean basin based on data from various sources cited in the text. Catchment sizes vary greatly, but note that the water fluxes for rivers draining the northern part of the basin, (a) to (e), are at least an order of magnitude higher that those draining the east and south of the basin, (f) to (i). 


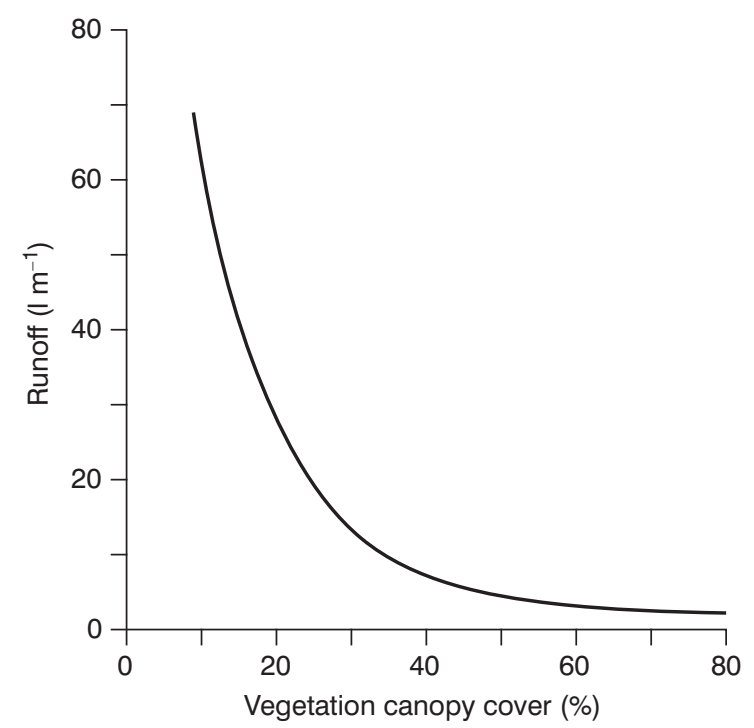

Fig. 8.8. The relationship between relative runoff and vegetation canopy cover according to Elwell and Stocking (1976).

theoretical (Carson and Kirkby 1972), experimental (Francis and Thornes 1990), and field investigations (Bochet et al. 2006). In the last paper, the authors found that, for the three species of Mediterranean shrub considered, whereas total vegetation canopy and litter cover reduced soil loss and runoff rates, soil loss and runoff increased with plant volume.

A very careful and detailed study of the effect of canopy structure on rainfall intensity for three common shrub species of the western Mediterranean (Anthyllis cytisoides, Stipa tenacissima, and Retama sphaerocarpa) was undertaken in laboratory simulations by GarciaOrtiz (2006). The species are shown in Figure 8.9. She found significant differences between species in canopy drip and through-fall volumes (as a percentage of the precipitation) and a correspondence between the main partitioning pathways and the root system type of the species was identified. Species with a deep root system were more efficient at redistributing rain by stem flow whereas species with a shallow root system redistribute rain mainly as canopy drip (Stipa tenacissima). Retama sphaerocarpa is the species with the least canopy storage, while Anthyllis cytisoides has the highest. The effects of rainfall intensity could not be fully explored and there is a need here for further research. It appears that Darwinian selection has led to plant morphologies that efficiently use the available rainfall to ensure their survival and may explain why these species are so abundant.

\section{Deforestation and Catchment Hydrology}

It follows that changes in the vegetation cover will transform the runoff regimes of Mediterranean catchments. This proposition is theoretically and empirically sound, but the results of studies of deforestation have not always been so clear. This is partly because of the wide variations in what is regarded as 'forest', because deforestation covers a wide variety of patterns of cutting within a catchment and because post-deforestation recovery depends on the sequence of weather in the years following cutting. These factors have been studied in detail by Obando (2002) in a semi-arid Mediterranean environment and the results suggest caution is needed in overenthusiastic endorsement of reafforestation as a strategy for reducing runoff.

Chirino et al. (2006) concluded from their study of the effects on runoff of a thirty-year-old Aleppo pine plantation in south-east Spain that the conservation of natural communities or the restoration of semi-arid ecosystems with native shrub species can be as effective as reafforestation in managing runoff and erosion as suggested by Francis and Thornes (1994). The same care needs to be exercised when claiming major impacts on catchment runoff resulting from fire and grazing. A large number of studies have been carried out on the effects of fire on water and sediment yield in the Mediterranean (Wainwright and Thornes 2003). Most of these results demonstrate an increase of at least one order of magnitude in both runoff and sediment yield. Variations in the intensity of the burn yield different results, as shown by Inbar (1992). The impacts of fire are largely in changing the infiltration properties of soils by changing their hydrophobic properties. These changes have to be balanced against the positive benefits of both reafforestation and grazing. As with soil erosion, the issue is simply not clear cut, nor are the conclusions uniform (Chapter 20). Chapter 19 deals with the wildfire hazard more generally in the Mediterranean.

\section{Cultivation and Catchment Hydrology}

There is less doubt about the impacts of cultivation on catchment hydrology, though still some scope for disagreement. Rapid runoff from hillslope and channel systems is a major catchment management issue across the Mediterranean region (Figure 8.10a). Wainwright (1996) examined the controls on runoff in the September 1992 flood in southern France in the basin of the River Ouvèze. Although the flooding was principally a result of the high rainfall intensities that occurred 

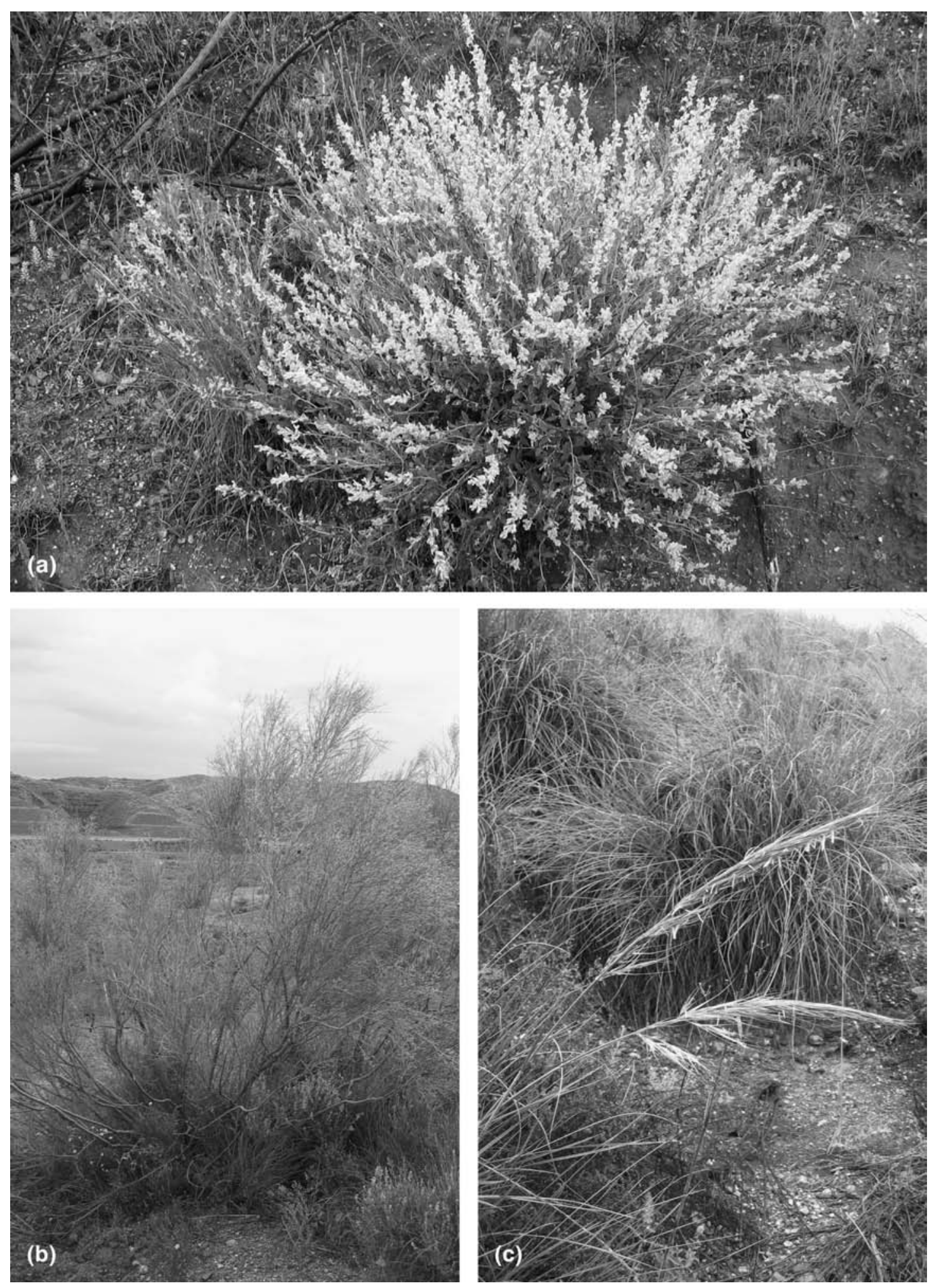

Fig. 8.9. The species used by Garcia-Ortiz in her study of rainfall partitioning by different Mediterranean plants. (a) Anthyllis Cytisoides (b) Retama retamo (c) Stipa tenecissima. The Retama is about $2 \mathrm{~m}$ high (photos: John Thornes). 

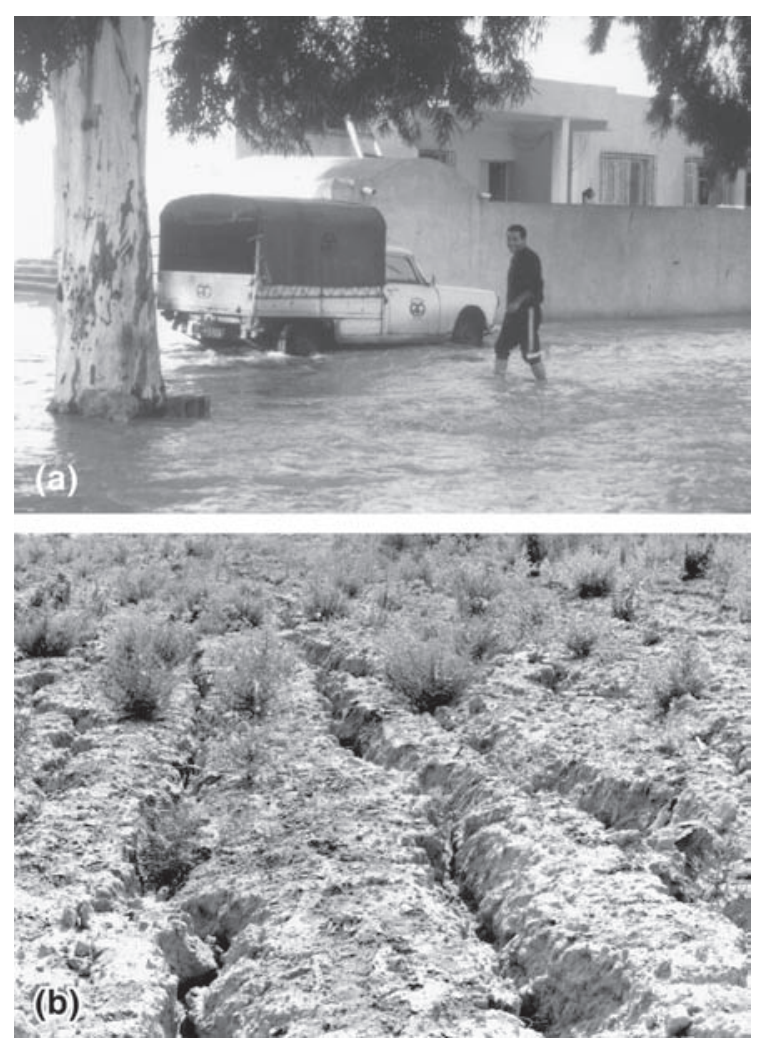

Fig. 8.10. Flood flows and erosion in Mediterranean catchments. (a) Runoff during a flash flood in Tunisia (photo: lan Foster). (b) Deep rill erosion on sloping agricultural land in the western Peloponnese, Greece (photo: Jamie Woodward).

in the catchment, experimental and modelling evidence suggest that the severe flooding could be explained by runoff production in the agricultural areas on the lower slopes and terraces immediately upstream of the village of Vaison, as well as from the badland areas which are concentrated more in the upland areas of the catchment. He indicated that cultivation practices encouraged flow concentrations, accentuating the links between slope and channel. An experimental study, using digital simulation, by Kirkby et al. (2002) indicated how steepness of the terrain and the direction of ploughing, relative to the main slope direction, influenced the volume of runoff. Figure $8.10 \mathrm{~b}$ shows how heavy rainfall and overland flow on bare and steeply sloping agricultural land in the Alfios River basin of the western Peloponnese can lead to the formation of deep $(>60 \mathrm{~cm})$ rills and the loss of valuable topsoil.

As with deforestation and cultivation, the argument about the impacts of grazing on catchment runoff is not that it is unimportant. It is that the activity is so diverse and its intensity so variable through time that it is difficult to predict the outcomes of these human modifications on catchment runoff and river regimes in Mediterranean environments. Nevertheless, because the effects of vegetation on runoff are reasonably well understood, they provide us with a tool for managing grazing in a way that optimizes runoff and sediment yield by assigning areas for grazing use (Thornes 2007).

\section{Direct Changes to Catchment Systems}

\section{Terraces and Water Harvesting}

One of the most ancient and widely practised direct water control measures in the Mediterranean has been the construction of agricultural terraces (Figure 8.11) (Grove and Rackham 2003; Chapters 6 and 7). This is a skilful procedure. The terraces have to be easy to cultivate with draft animals (oxen or mules), accessible, and fairly flat, and yet designed to ensure that the water is conducted away safely without undue erosion. Water infiltrates into the terraces and, if hydraulic pressure builds up inside the terrace, it can lead to piping which in turn can produce deep shafts big enough to swallow animals and machines.

In North Africa and the Levant, the management of catchments has become a fine art, in order to conserve water for agriculture (Evenari et al. 1982). This procedure is called water harvesting. In carefully selected areas, vegetation is removed and the soil 'crusted' by trampling or hardening. Then the runoff from these crusted surfaces is conveyed by lined ditches into tanks, cisterns (Figure 8.12), or aljibe (tanks with rounded roofs that collect evaporated water) to be used for crop irrigation. This practice was well established in Roman times and used by Arabic farmers in the Maghrebian states and Iberia (Gómez-Espin 2004). The modern equivalent of the ancient stone-fronted terraces is extensive contour benching over large areas, usually by bulldozers. These are direct conservation measures for runoff on the hillslopes and may be used for flood protection.

\section{Check Dams and Reservoir Development}

Direct measures in the channels range from small check dams, a few metres high, to major reservoirs (Figure 8.13a, b). Check dams serve multiple purposes. In addition to reducing the amount and velocity of runoff from headwater channels, they also store transported 


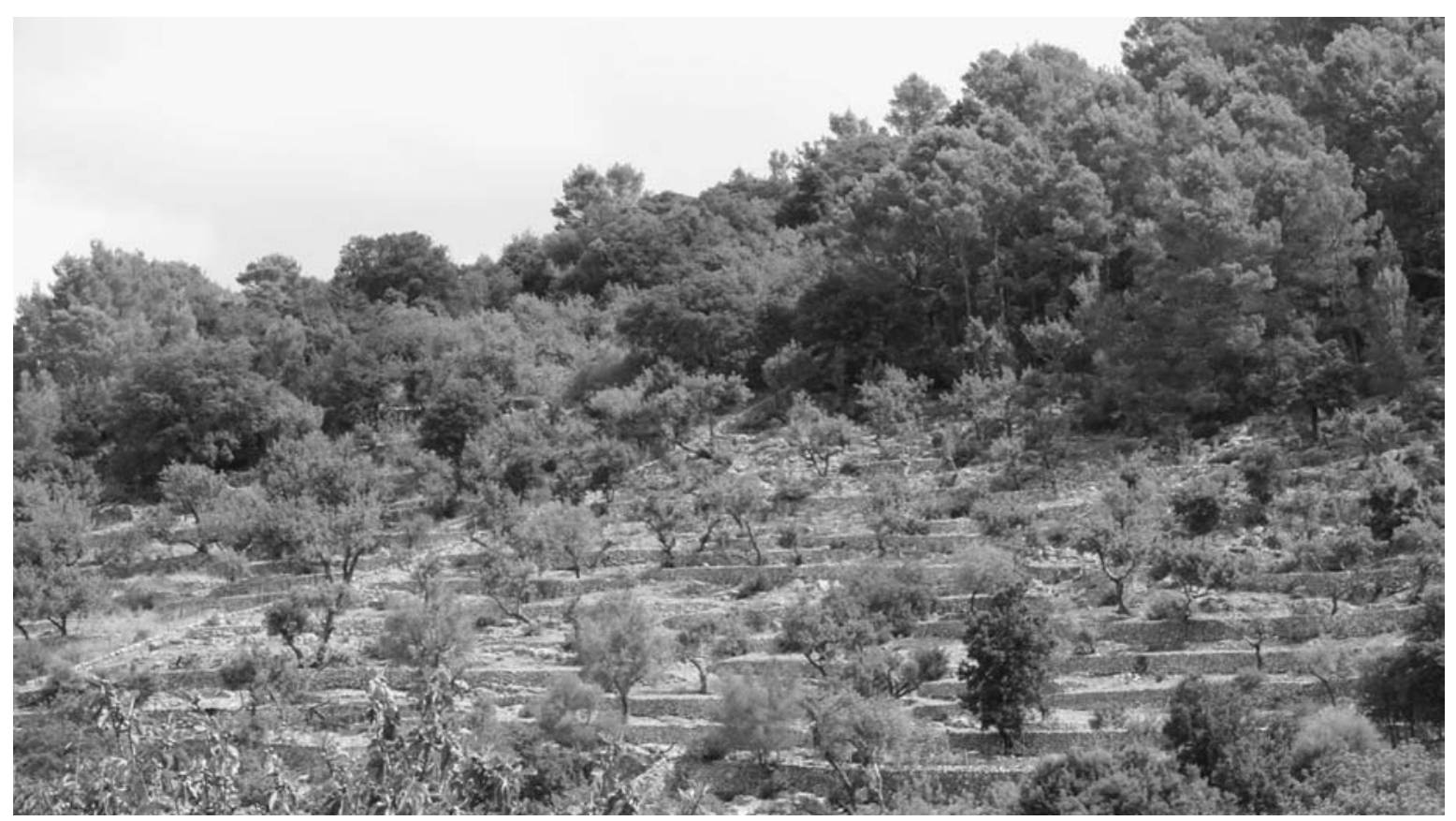

Fig. 8.11. Stone-walled terraces on hillslopes near Campanet in central Majorca (photo: Jamie Woodward).

sediment and provide flat areas for cultivation, into which water quickly and easily infiltrates. Another small, direct control on runoff in channels that dates back to the ancient water-control era of the western Mediterranean is the boquera system. Walls are constructed in the channel floor to lead flood water into fields, or boqueras, on either side of the channel where water is stored, as soil moisture, to provide for cereal and tree crop cultivation. Mill sites also abound in channel systems and the power provided can then lift irrigation water into canal systems that may redistribute it across hundreds of hectares. Other minor direct features include tunnels constructed beneath river beds - the water infiltrates into the gravels and then into permeable brick-lined tunnels that may convey it as much as $30 \mathrm{~km}$ to provide town water supplies. Many inter-basin water transfers were introduced in the Mediterranean region during the Roman Period as the expansion of urban settlements increased the demand for water supplies. In southern Epirus (north-west Greece), for example, the city of Nikopolis, founded by Octavius Augustus in $30 \mathrm{BC}$, required the construction of a major aqueduct (50 km in length) that brought large volumes of water from the Louros Valley to the north to the 300,000 residents of the city (Mavromati and Chryssaidis 2007; Vita-Finzi 1978).

Above all, the runoff of rivers has been modified by the great reservoirs the construction of which commenced at the end of the nineteenth century in the period of $L a$ Grande Hydraulique. Some of these have already filled with sediments (Figure 8.13b). In Murcia, Spain, the wall of the Valdeinfierno reservoir was extended vertically, while in the Puentes reservoir immediately downstream (Figure 8.14a) a new wall has been constructed in front of the original. This construction of reservoirs has had a marked impact on the flow regime of the Segura River (Figure 8.14b), completely changing it from one dominated by peak flow in winter months, to one of peak (but lower) flows in summer months. These changes reflect not only the winter rains, but also the summer demand for irrigation. The summer discharges are now controlled 'ecological' flows required to maintain the ecological health of the river as it passes through the city of Murcia and beyond. As a consequence of these and other measures, the quality of the Segura has notably improved since 1972 . Because of the seasonal characteristics of both the industry (fruit processing) and the flows, the smaller 


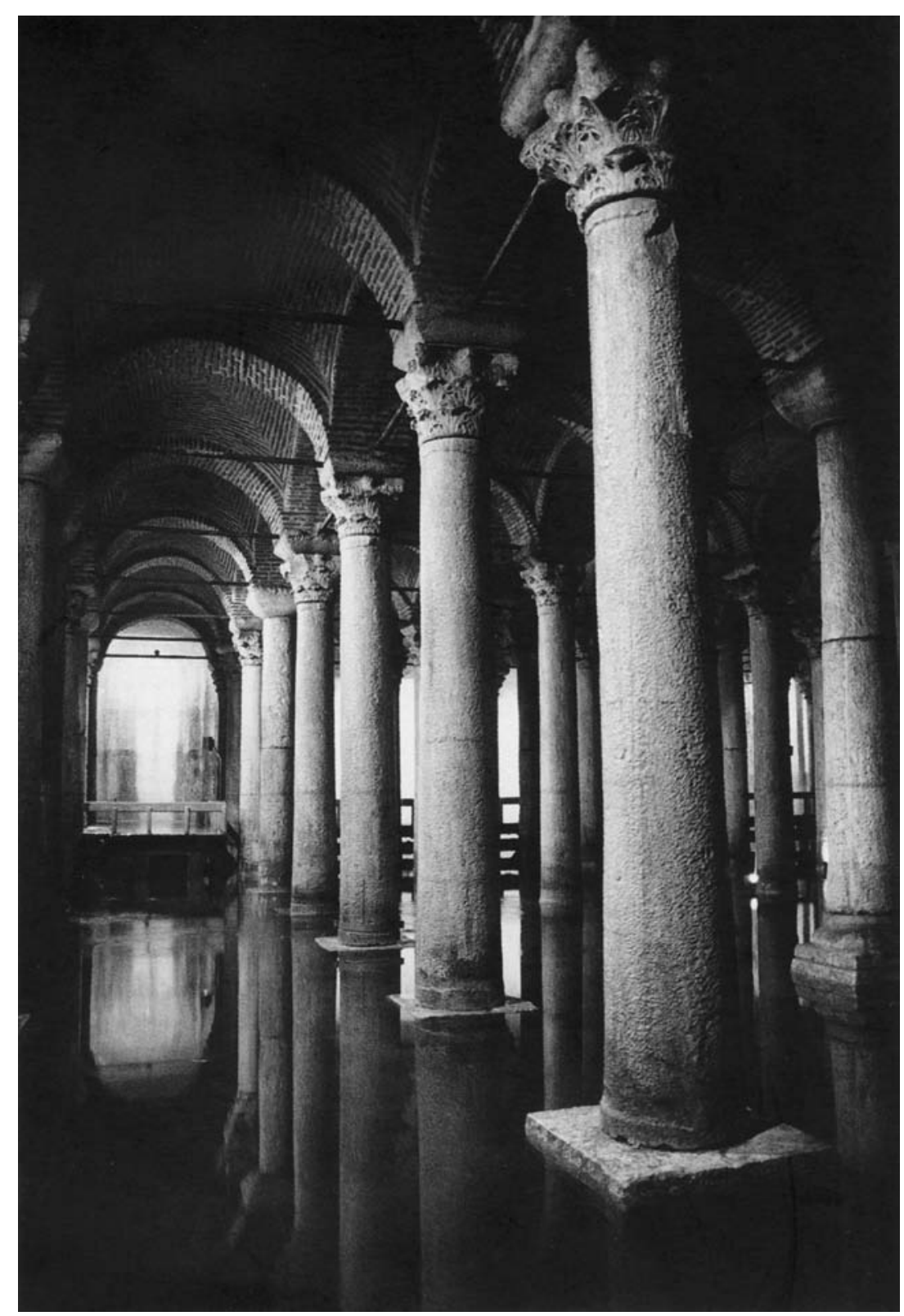

Fig. 8.12. A water cistern directly under the former Greek agora in Ptolomais, Libya. It receives water via an aqueduct from mountain springs $25 \mathrm{~km}$ to the east (photo: courtesy of Paul Fordham).

tributaries, such as the Mula, were heavily contaminated by stagnant pools in the summer months (Victoria Jumilla and Vicente Lopez 1986). These conditions impose special demands for integrated river management under the European Water Framework Directive. Establishing an appropriate balance between water storage, water abstraction, and the ecological needs of channel systems is a major water resource management issue across the Mediterranean (Thornes and Rowntree 2006). The loss of water storage capacity to sedimentation is a particularly important water resource management issue in Mediterranean northwest Africa. In Morocco, the average annual water storage loss to sedimentation in the thirty-four largest 

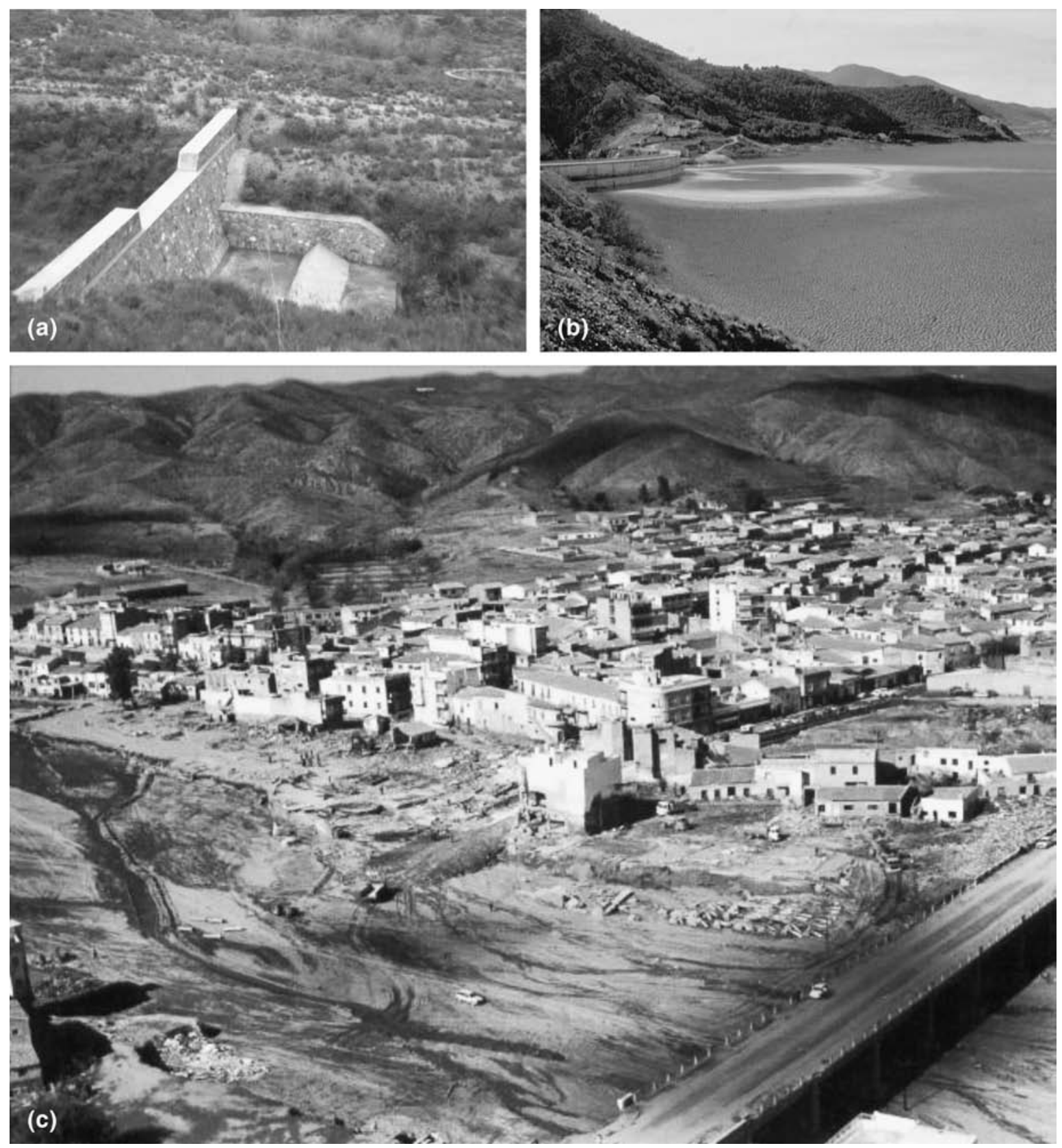

Fig. 8.13. (a) A newly built check dam in the Segura River basin, south-east Spain. The water and sediment will fill the area to the left of the main wall. The apron and raised hump to the right are to prevent a scour pit developing during flood events and undermining of the main wall. (b) A sediment-filled reservoir: Valdeinfierno Reservoir, Murcia, Spain. The water storage capacity is now less than 5 per cent of the original. The foreground is wave-rippled sediment and not water. The location of this reservoir is shown at Figure 8.14a (photos: John Thornes). (c) Oblique air photograph of the town of Puerto Lumbreras and the Rambla Nogalte (see Figure 8.14a) in the aftermath of the large flood in October 1973 (http://www.puerto-lumbreras.com/galeria.asp?galeria=3). 

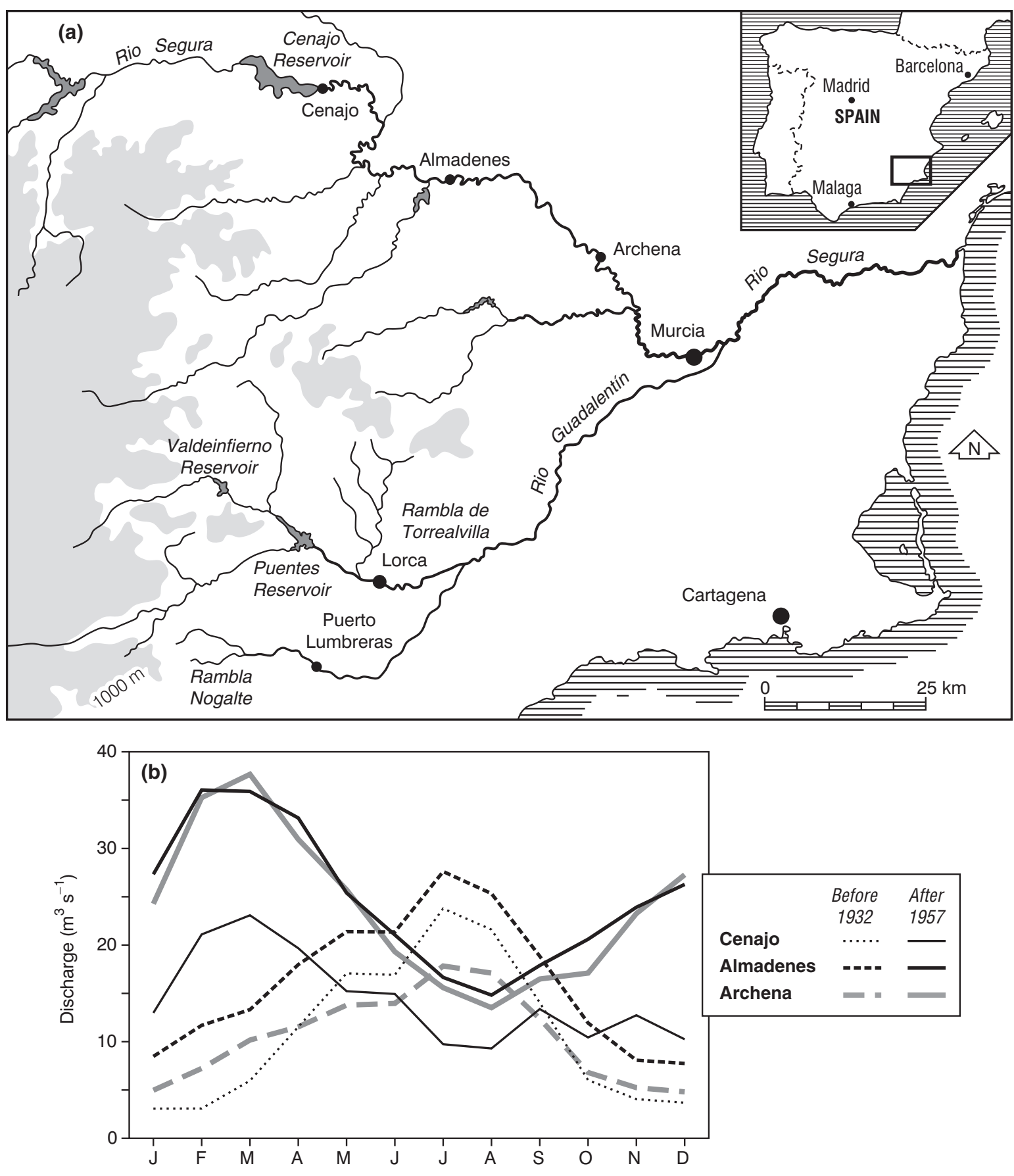

Fig. 8.14. (a) Map of the Segura River basin $\left(18,800 \mathrm{~km}^{2}\right)$ in south-east Spain, showing the location of the sites shown in Figure 8.13 . (b) The impact of reservoir construction on the monthly distribution of flows in the Segura River in Murcia, south-east Spain. The three gauging stations are shown in (a) above. 
reservoirs amounts to about 0.5 per cent (Lahlou 1988). Reservoirs in Algeria are estimated to be losing 2-3 per cent of their storage capacity each year and this equates to about 90 million $\mathrm{m}^{3}$ of water (Grenon and Batisse 1989).

\section{Runoff Generation at the Local Scale}

In the previous section we looked at how the catchment runoff of Mediterranean rivers has been both indirectly and directly modified over the centuries by human activities. In this section the main natural controls of runoff generation at the local scale are considered.

With the coming of remote sensing, hydrological studies of Mediterranean catchments included modelling runoff on the basis of the distribution of rainfall over the catchment and its distribution of intensity through time. It became recognized that soil conditions controlled infiltration rates and hence runoff, especially where vegetation was very scarce. A growing body of research indicated that surface crusting was also important. This crusting might be compacted soils a few millimetres thick formed under heavy rain, or chemical precipitation such as Mediterranean calcretes (Chapter 6). The crust can also be formed by lichens or other micro-organisms. These various crusts seriously impede infiltration rates and produce more excess runoff. In large catchments, these variations in surface texture and therefore runoff can be enough to control the volume and timing of runoff and therefore of stream hydrographs. Even the simple discrimination between bedrock runoff and alluvial surface runoff can be enough to improve runoff predictions from dryland catchments greatly. The term 'hydrologically similar surfaces' (HYSS) is used to describe surface properties that affect runoff generation. A study of the $1,400 \mathrm{~km}^{2}$ Nahael Zin catchment in southern Israel by Lange et al. (1999), using remote sensing to identify HYSS and GIS techniques to map and model runoff, removed much of the uncertainty in runoff prediction. Field data were used to specify the characteristics of the HYSS.

By way of clarification of this emerging concept, Bull et al. (2000) used an improved infiltration model coupled with digital runoff simulation to examine the major controls on runoff generation at different scales. The study was based on observations of the Nogalte and Torreavilla catchments in south-east Spain. At the hillslope scales, runoff intensity was recognized by classifying the morphological evidence that ranges from 'no evidence of flow' to 'streams and gullies $>1 \mathrm{~m}$ deep'. The different morphological runoff types are arranged in different zones on different lithologies according to the length-slope product. For the simulated storms, the storm structure (cell size and intensity) was not important in producing at-a-point runoff even over a simulated catchment of $1,000 \mathrm{~km}^{2}$. However, at these larger scales, the basin morphology has an important control on runoff generation, because it determines water storage on the hillslope and transmission losses into the channel bed. Also at this scale, the connectivity of the channel network becomes very important.

In summary, the most important control on runoff for these simulated conditions is variations in intensity through a storm. For observed data on catchment characteristics (e.g. shape and connectivity) and storm cell size, the effect of storm size did not lead to large errors, if estimates of catchment runoff were made from a single central rain gauge. Large divergence only appeared for areas of $1,000 \mathrm{~km}^{2}$ or more. The final factor of great importance is the areal distribution of crusting properties as indicated above (Chirino et al. 2006).

Runoff generation in Mediterranean catchment systems is rather different from that of weakly-seasonal temperate environments, as discussed by Beven (2002). In this important contribution, Beven described our perceptions of what constitutes the behaviour of ephemeral channels: the complexity of the controlling processes, the strong non-linearity of that behaviour, the extreme heterogeneity of the runoff surfaces, and the limited storm extents in space and time (Figure 8.15 Chapter 18). He concluded (p. 62) that 'We still have much to learn about runoff generation in semi-arid catchments.' In particular he questioned the assumption that flow in these catchments was dominantly Hortonian overland flow (when rainfall intensities are significantly higher than infiltration capacities). Kirkby (1969) showed that in temperate environments this was rarely the case and supported Dunne and Black's thesis that hydrological modelling must accommodate sub-surface flow, especially where flow is convergent (Dunne and Black 1970). Beven (2002) went on to review evidence for subsurface flow even in dryland systems, reaching the conclusion that, in Mediterranean catchments, this can be readily accepted as occurring under winter conditions.

The main problems are choosing appropriate infiltration models and capturing the huge heterogeneity at different scales, even down to the level of the individual plant (Figure 8.9). This seems to require an alternative approach to fully distributed hydrological models or 

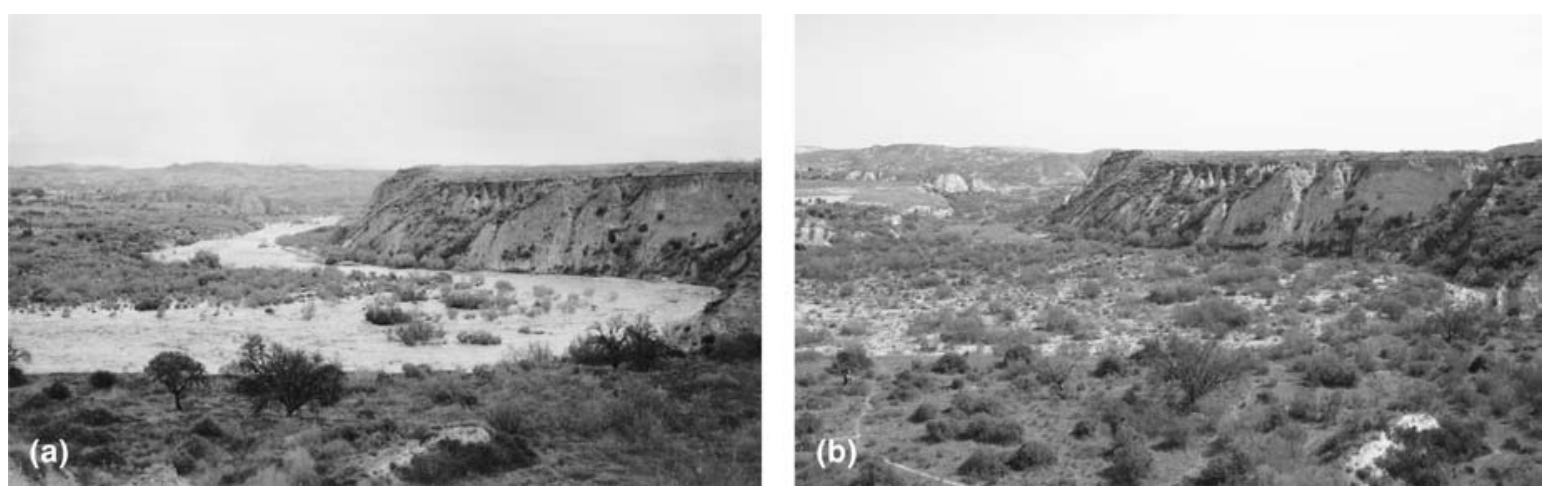

Fig. 8.15. The Río Aguas at Urra in the Sorbas basin, Almeria, south-east Spain. (a) The river in flood with turbulent flows and high suspended sediment concentrations (photo: courtesy of Joe Walsh) and (b) when the channel is dry in April 2006 (photo: Jamie Woodward).

a better management of the parameterization problem. An example of the former is the stochastic approach to modelling, as in the work in the Rambla de Algeciras (Murcia) by Conesa-Garcia and Alonso-Sarria (1997) or by Shannon et al. (2002) which proposes a Markov routing approach to ephemeral channels. Beven's chapter concluded with the second approach-improving the parameterization.

This may seem a far cry from Mediterranean rivers, but the continued demand for water and buildings in the coastal zone where the rivers and ramblas (ephemeral gravel-floored channels) meet the sea means that flash floods there can have disastrous effects on property, so that effective identification of flood-prone areas is a very high priority (Chapter 18). Although this can in part be achieved by historical evidence and experimental hardware models (e.g. for groundwater recharge), mathematical hydrological modelling also offers a route that can be pursued.

\section{Catchment Sediment Yields}

The steep relief of Mediterranean river basins, the widespread occurrence of erodible rock types, and the heavy storm events that can generate rapid surface runoff combine to produce high suspended and bed sediment loads across the region. The erosion processes responsible have been reviewed in detail in Chapter 6 . While there is little doubt that human activity is also important - and bare fields with limited soil conservation measures can lose large volumes of top soil during storm events (Figure 8.10b) - the underlying topographical, lithological, and climatic controls combine to produce an environment with much higher sediment fluxes per unit area than more temperate areas in central and northern Europe for example (Woodward 1995; Milliman and Syvitski 1992).

\section{Suspended Sediment Yield}

Dedkov and Moszherin (1992) have attempted to distinguish between the anthropogenic and natural or background sediment yield of river basins in mountain environments across the world. This is a very difficult task and the database for mountain river basins is very patchy indeed. However, they used land use type and extent to classify catchments into natural or modified states. Many would dispute this finding, but their analysis suggests that the sediment loads of mountain river systems in the Mediterranean are influenced by human action to a greater extent than those in any other climatic zone (Figure 8.16). It is, however, difficult to generalize about such a diverse region when there are so many variables to consider. Nonetheless, what does seem clear is that within the Mediterranean region, clear contrasts are evident in the magnitude of suspended sediment yields from catchments in the north and south with the latter typically an order of magnitude higher that the former (Milliman and Syvitski 1992; Woodward 1995). Table 8.1 contains data for two large river catchments in the northern Mediterranean that drain into the Aegean Sea to the west of Thessaloniki in north-east Greece. The Axios $\left(23,747 \mathrm{~km}^{2}\right)$ and Aliakmon $\left(9,250 \mathrm{~km}^{2}\right)$ rivers drain humid headwater catchments with elevations well over 2,000 $\mathrm{m}$ and have mean annual water fluxes of 5,030 and 2,292 million $\mathrm{m}^{3}$ per year respectively (Kapsimalis et al. 2005). These catchments-which include a range of land use typeshave mean annual suspended sediment yields of 555 and $670 \mathrm{t} \mathrm{km}^{2} \mathrm{yr}^{-1}$, respectively, which are much lower than the typical yields for catchments in the Maghreb 
John Thornes et al.

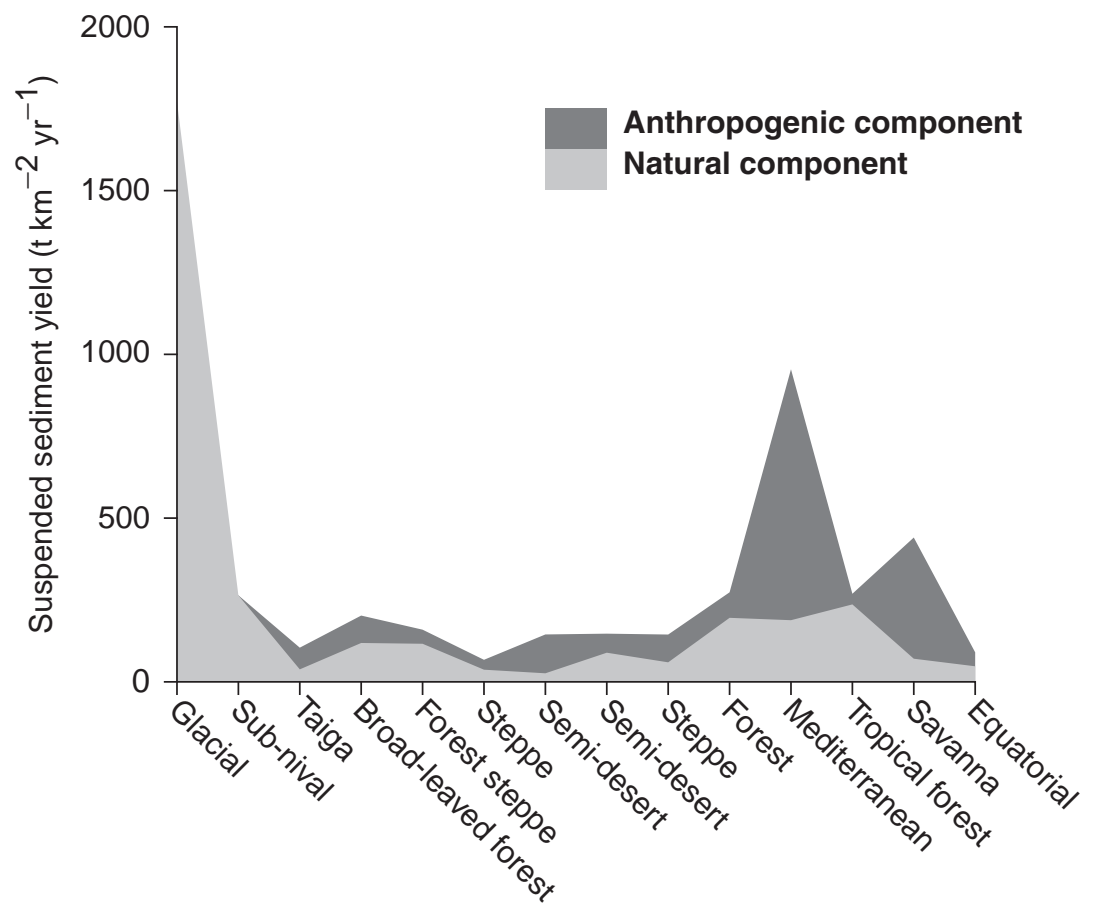

Fig. 8.16. Suspended sediment yield from river basins in mountain environments in different climate and vegetation zones based on the analysis of Dedkov and Moszherin (1992).
(Lahlou 1988; Woodward 1995; Woodward and Foster 1997). In a review of the sediment yield of African rivers, Walling (1984) identified the narrow strip of upland catchments across Mediterranean north-west Africa as the highest yielding river basins on the continent. Suspended sediment yields from many of these catchments range from 1,000 to $5,000 \mathrm{t} \mathrm{km}^{-2} \mathrm{yr}^{-1}$. In an average year, the total annual suspended sediment load from river systems in the Maghreb that drain to the Mediterranean Sea is about 100 million tonnes (Probst and Amiotte Suchet 1992), and the flood events responsible are commonly characterized by very high suspended sediment concentrations.

Network expansion by gully development in soft sediments can provide an important source of suspended sediment in Mediterranean catchments (Figure 8.17a). Thick, single-event accumulations of fine-grained sediments in channel and floodplain zones are indicative of high suspended sediment concentrations and loads (Figure 8.17b). High suspended sediment loads are a feature of many Mediterranean river basins but this is often strongly controlled by catchment lithology. Figure 8.18 shows how sediment yields in Moroccan catchments are markedly reduced where resistant rocks such as quartzites and granites are important. In contrast, where
TABLE 8.1. Water and sediment fluxes from the Axios and Aliakmon rivers that drain into the north-west Aegean Sea

\begin{tabular}{lrc}
\hline & Axios & Aliakmon \\
\hline Catchment area $\left(\mathrm{km}^{2}\right)$ & 23,747 & 9,250 \\
Maximum elevation $(\mathrm{m})$ & 2,800 & 2,200 \\
Mean annual rainfall $(\mathrm{mm})$ & 650 & 750 \\
Land use (\%) & & \\
$\quad$ Forest cover & 16.9 & 19.0 \\
Uncultivated area & 5.9 & 40.0 \\
Arable land & 75.4 & 39.3 \\
Urban area & 1.7 & 1.3 \\
Wetland & 0.1 & 0.4 \\
Water fluxes (106 $\mathrm{m}^{3}$ ) & & \\
$\quad$ Mean annual discharge & 5,030 & 2,292 \\
Monthly maximum discharge & 8,800 & 4,320 \\
$\quad$ Monthly minimum discharge & 1,545 & 662 \\
Material fluxes $\left(10^{6} t \mathrm{yr}^{-1}\right)$ & & \\
Suspended sediment load & 13.2 & 6.2 \\
Dissolved load & 1.7 & 1.2 \\
Bed load & 2.6 & 1.3 \\
Total load & 17.5 & 8.7 \\
\hline
\end{tabular}

Source: Modified from Kapsimalis et al. 2005.

shales, marls, flysch, and other erodible lithologies are extensive, sediment yields can exceed $6000 \mathrm{t} \mathrm{km}^{2} \mathrm{yr}^{-1}$. 

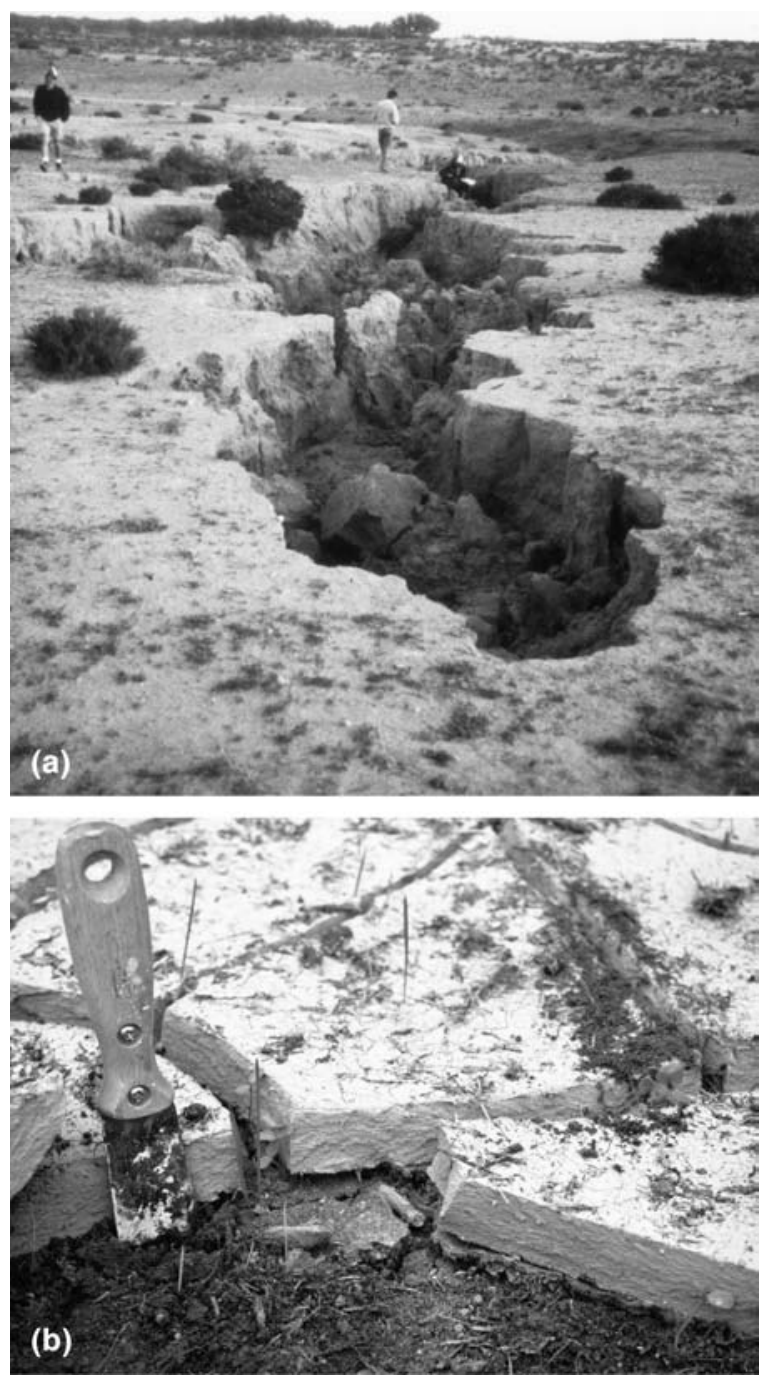

Fig. 8.17. (a) Gully erosion in soft sediments in central Israel (photo: Ian Foster) (b) A veneer of fresh suspended sediments deposited within the channel zone of the Torcicoda River in central Sicily (photo: Jamie Woodward).

River monitoring studies and reservoir sediment surveys have shown that river catchments in the Maghreb region of North Africa have some of the highest suspended sediment yields in the circum-Mediterranean zone (Woodward 1995; Woodward and Foster 1997; McNeill 1992). Water storage losses to sedimentation are a major concern for water resource managers in Morocco, Algeria, and Tunisia (Chapter 21).

In a recent global-scale analysis of human impacts on the flux of sediment from the land surface to the oceans,
Syvitski et al. (2005) estimated that human activity (mainly through land use change in river catchments leading to soil erosion) has increased the global sediment load of river systems by $2.3 \pm 0.6$ billion metric tons per year whilst simultaneously reducing the flux of sediment reaching the marine environment by $1.4 \pm 0.3$ billion metric tons per year due to sediment retention in reservoirs. Dam construction for water storage has been a favoured response to the pronounced seasonality in Mediterranean river flows since Roman times and many of today's catchments contain impoundments at a range of scales. In the case of river systems draining to the Mediterranean and Black Seas, Syvitski et al. (2005) have estimated that 30 per cent of the fluvial suspended sediment flux is retained behind reservoirs and this compares to a global average of 20 per cent. Interestingly, their analysis also shows that Mediterranean river systems have the lowest proportion of summer (JJA) and autumn (SON) sediment fluxes of any landmass or ocean basin at 9 and 7 per cent respectively of the annual total.

\section{Bed Load Fluxes}

Information on bed load transport in Mediterranean river systems is generally much patchier than the database on suspended sediment transport. However, valuable datasets are available from Israel in particular where pioneering work on the ephemeral rivers of the Negev has provided important insights into the dynamics of the region's dryland rivers (e.g. Laronne and Reid 1993; Reid and Laronne 1995; Reid et al. 1998). Bed load transport is difficult to measure and it poses particular logistical problems in semi-arid and arid river catchments because floods are so infrequent and unpredictable. In this context, it is useful to consider some of the hydrological characteristics of dryland catchments in the Mediterranean. A well-researched example is the Nahal Eshtemoa catchment $\left(119 \mathrm{~km}^{2}\right)$ that drains part of the southern Hebron Hills and is typical of the river systems of the northern Negev Desert. This catchment receives an annual rainfall input of 220 to $350 \mathrm{~mm}$ within a region where the potential evaporation is commonly $>2,000 \mathrm{~mm}$ per year. This produces large soil moisture deficits which, in combination with sparse vegetation cover and low infiltration capacities, can produce overland flow within minutes of the onset of rainfall (Reid et al. 1998). Flow duration analysis of the Nahal Eshtemoa catchment for the period 1991-5 revealed that the channel conveyed flows on only seven days per year ( $2 \%$ of the time) and that overbank flooding took place for only 0.03 per cent of the time (Reid et al. 1998). The number of flash floods over this period 
John Thornes et al.

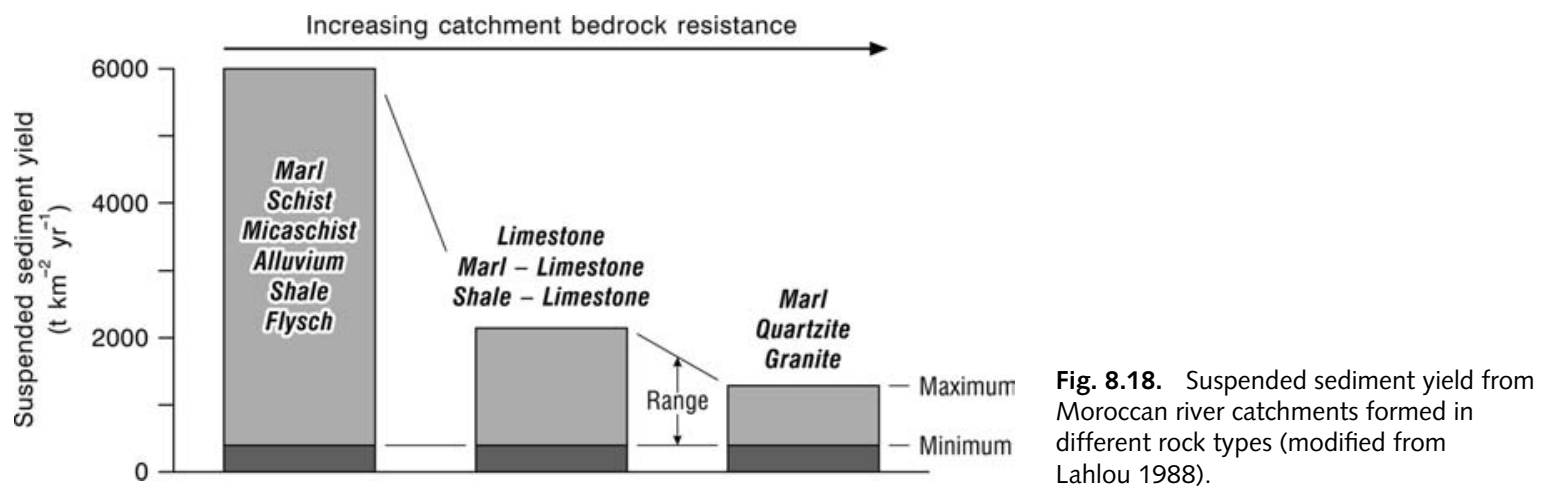

ranged from two to seven per year and most were produced by convective storms. The trunk stream hydrographs for these events show very spiky behaviour with most of the floods showing very steep rising limbs and multi-peaked hydrographs. Due to the roughness of the coarse-grained channel bed, flash-flood bore velocities are typically quite slow falling within the range $1-1.5 \mathrm{~m}$ per second (ibid.). Such infrequent and unpredictable flow regimes are typical of the eastern and southern Mediterranean and contrast markedly with the more humid regions in the north (Figure 8.7).

The database on bed load flux in the ephemeral river systems of the Negev shows very high rates of sediment flux in comparison to perennial rivers of more humid environments. Laronne and Reid (1993) have argued that bed load data for the Nahal Yatir catchment show it to be 400 times more efficient at transporting coarse sediment than some of its perennial counterparts in more humid zones. Annual bed load sediment flux in the neighbouring Nahal Eshtemoa system was calculated as 4,641 tonnes or 39 tonnes $\mathrm{km}^{-2}$ while suspended sediment yield over the same period was 433 tonnes $\mathrm{km}^{-2} \mathrm{yr}^{-1}$ giving a bed load to suspended load ratio of 1:11 (Reid et al. 1998).

Data on bed load transport are now also available for perennial river systems in the mountains of the Mediterranean basin. For example, Garcia et al. (2000) employed an automated bed load monitoring system in a small catchment $\left(35 \mathrm{~km}^{2}\right)$ in the upper reaches of the Todera River in the coastal mountains of Catalonia in north-east Spain and monitored five flood events between 1995 and 1996. A key observation was the marked variability in bed load flux during the course of each flood event. Distinctive pulses of bed load transport were associated with sudden increases in flow depth and bed load response to hydraulic variables such as critical shear stress varied markedly between flood events. Much further downstream in the lower, ephemeral, part of the same river basin, Rovira et al. (2005) assembled a fluvial sediment budget for an 11-km reach that lies just upstream of the basin outlet $\left(894 \mathrm{~km}^{2}\right)$ to the Mediterranean Sea. For the period from January 1997 to June 1999 they showed that the bulk of the total sediment load was transported as coarse bed load sediment. Around 156,000 tonnes of sediment $(80 \%$ as bed load and $20 \%$ as suspended load) entered the study reach and approximately 107,000 tonnes $(83 \%$ as bed load and $17 \%$ as suspended load) of sediment exited the reach and were discharged to the coastal zone and the Mediterranean Sea. Using repeat field surveys of the channel and floodplain zone in association with monitored sediment flux data, Rovira et al. (2005) estimated that 49,600 tonnes of sediment were deposited within their study reach over this period giving a mean rate of sediment accumulation on the channel bed of $6.8 \mathrm{~mm}$ per year.

The extraction of bed load materials for aggregates and other commercial uses is widespread in the Mediterranean and this activity can result in dramatic modifications to coarse sediment budgets in river channel systems (Nicholas et al. 1999). Information on bed load transport should form part of the design of catchment management plans to ensure that such resource exploitation is sustainable in the long term. This aspect of direct river channel modification is discussed in more detail in Chapter 11.

\section{River Catchment Management and Hazard Mitigation}

\section{Floods and Flood Protection}

Damage and loss of life from floods is commonplace in Mediterranean river catchments (Chapters 3 and 18) and appears to have been so throughout history. For south-east Spain, Gil Olcina (1971) records the floods of 
Lorca (Murcia) in the seventeenth century and Pocklington (1986) describes flooding of the huerta (cultivated area) of Murcia in Arabic times. Chapter 11 documents flood histories for the Little Ice Age in various parts of the Mediterranean including southern France, Corisca, Crete, and north-west Greece.

An example from recent times was the flash flood of Puerto Lumbreras (Figure 8.13c). On 18/19 October 1973 an intense storm crossed southern Spain, from Torremolinos in the west to Benidorm in the east. Over $250 \mathrm{~mm}$ of rain fell on the mountains of the Sierra Nevada in the headwaters of rivers that drain to the Mediterranean coast, the Guadalhorce, Guadalfeo, Andarax, and Almanzora. The storm created immense damage to roads, bridges, irrigation installations, and agricultural land. It caused severe loss of life in the village of La Rabita, where homes were destroyed by a mudflow emerging from a small canyon. In the town of Puerto Lumbreras (Figure 8.13c), where the weekly market was being set up in the dry river-bed, the flood wave washed away the entire market. Houses and cave dwellings and Moorish irrigation canals were destroyed by the on-rush of water.

Today the scene is more tranquil. At Puerto Lumbreras, huge walls have been constructed on either side of the channel to protect the remaining town. The catchment of the Río Nogalte (Figure 8.14a) has been contour ploughed and trees have been planted. Over a hundred check dams have been installed in the steep-sided tributaries (barrancos) by the government agency responsible for natural resources. The Ministry of Public Works has reconstructed roads and bridges. Houses have been repaired, sub-alluvial galleries reinstated and the market continues to operate in the river-bed on a regular basis. The more protection that is provided, the more risk the population appears to be prepared to take. Although statistics suggest the event has a probability of occurring about 1 in 500 years, an equally disastrous storm occurred in 1982 in the Valencia area, immediately to the north. This story is repeated frequently across the Mediterranean and reflects a combination of intense storms, poor vegetation cover, and a long period of land management that encourages high and rapid runoff from mountainous terrains and impervious soils. The storm and flood hazards in the Mediterranean region are discussed in greater detail in Chapter 18.

\section{River Catchment Management}

In the EU MEDALUS (Mediterranean Desertification and Land Use) Project, the role of flooding in the Guadalentin River basin (Figure 8.14a) was recognized as a component of the problem of desertification and a plan was devised to manage the problem through land use control in the catchment of one of its tributariesthe Rambla Nogalte (Rojo Serrano et al. 2002). This was already partly underway in the remedial work following the 1973 flood.

The rainfall of the basin ranges from $200 \mathrm{~mm}$ per year in the lowland areas, to $800 \mathrm{~mm}$ in the mountain headwaters and the rainfall is characterized by high intensities and short duration. Half of the basin has slopes greater than 12 per cent (at which erosion starts) and about one-third has slopes greater than 20 per cent (the overland flow-rilling threshold). A very small area of the basin is covered with sclerophyllous forest in the mountains. At lower altitudes and over most of the basin, the conditions are too dry for oak woodland (Quercus rotundifolia), but pines (Pinus pineaster, nigra, and halepensis) can survive. At even lower altitudes, bushes of the matorral prevail. Overall, 45 per cent of the basin is covered with 'wildland' and only 25 per cent of the basin is covered by forest, with another 20 per cent by shrub and bush communities. Water scarcity, groundwater exploitation, and flood protection are the most important environmental issues, followed by soil erosion.

In the past, mechanized afforestation techniques in this catchment have been more effective than manual ones in decreasing hillslope runoff, retaining and storing as much water and moisture as possible (Rojo Serrano et al. 2002: 310). Pinus halepensis is the fundamental afforestation species. It is a Mediterranean species and its resistance to excessive sunshine means it has no need for shade when first planted. However, in the worst climatic and edaphic situations, this species is unable to reach forest status. In this study, specific management techniques were recommended for the Upper Guadalentin, ranging from better management of the existing forest and grazing areas, to restoration of saline soils in the lowland areas. This example provides a model approach that could be applied in many flood-prone areas of the Mediterranean and beyond.

In other management schemes, unexpected effects may lead to unexpected and undesirable results. Borel (1994) showed how the construction of the SerrePonçon dam in the headwaters of the River Durance in Provence had entirely changed the ecosystem of this steep gradient river. The barrage was completed in 1959. The pre-impoundment river experienced enormous seasonal variations, with very low flows in the summer droughts to devastating floods $\left(6,000 \mathrm{~m}^{3} / \mathrm{s}^{-1}\right)$. The Serre-Ponçon dam-with its 1270 million $\mathrm{m}^{3}$ of storage-now completely regulates the flow, but it is only one of a series of dams on the Durance. The 
flow is now more regular, with a diminished snowmelt flood in spring. Several new biotopes have appeared in the channel and floodplain complex and a significant increase in riparian vegetation, especially reed beds, has resulted in an increase in animal and plant diversity in the river corridor. The modified flow regime has also created a new corridor for the spread of plant and animal species. The changes in biodiversity highlight the need for good management and careful attention to the impact of changes on river ecosystems. This example also highlights a common problem throughout the Mediterranean region-the tension between what is desirable for mountain catchment areas and the resource needs of the littoral plains where economic activities and population are concentrated (Chapter 21).

\section{The Water Framework Directive}

In December 2000 the European Union published the Water Framework Directive (Directive 2000/60/CE). This is a legal requirement on all member states to create an information base and an implementation plan so that all inland and coastal waters will reach 'good status' by 2015 . They will do this by establishing a river basin district structure within which demanding environmental targets will be set, including ecological measures, for surface waters. Monitoring networks for water quantity and quality are patchy across the Mediterranean region and this represents a very significant management problem. The paradigm is now established and we briefly consider here whether it provides an appropriate model for Mediterranean rivers, either those already within the Union, directly or by association, or for those outside it.

This Directive reflects the emergence of three important paradigms of river management, worldwide. First, rather than seeking to continue the modification of rivers that has taken place throughout the last two millennia, river managers should seek to restore rivers as close as possible to 'natural' conditions (Brookes and Shields 2001). Second, to do this, the river must be seen as a product of its catchment and integrated catchment management (ICM) must be adopted. Consequently changes may be required in the catchment in order to restore the river. Third, this is part of an overall paradigm towards restoring nature that has come to the forefront of the environmental movement (Gobster and Hull 2000).

The Water Framework Directive carries with it extensive documentation, including specific guidelines about how to proceed with the implementation. These are more easily implemented for the temperate river basins of north and north-west Europe and even there they raise three key questions. First, which nature should it be? Many states of nature can be created-prehistoric, pre-industrial, or even pre-glacial (Hull and Robertson 2000). Second, can universal indicators be devised that are suitable for most aspects of river restoration in different environments, cultures, and socio-economic constraints? Third, can the rules, values, objectives, and procedures developed for the temperate rivers of northwest Europe be sensibly applied to the seasonally controlled humid and ephemeral rivers of the European Mediterranean?

\section{Concluding Comments: Problems and Prospects}

In the seasonal rivers of the Mediterranean there are quite different management priorities from those of temperate Europe. These include:

- Many rivers have high sediment yields, so the focus of interest in ICM is the erosion and transport of particulate matter in the catchment. Interest therefore has to focus as much on hillslope as channel process and more on semi-natural vegetation and agricultural land use than on recreation and forestry.

- The seasonality of flow and the existence of large flood events shift the thrust of the ecological argument as much to the channel beds and the flood corridors as well as to the water quality issues.

- Flooding is a high priority and consequently so is flood protection. The flashiness of Mediterranean rivers is well documented and deserves a high profile in restoration works. Insensitive elimination of water control structures in an overenthusiastic response to catchment management could destroy the work of centuries with disastrous outcomes.

- In several important examples in the Mediterranean, irrigation requirements are coupled to inter-basin transfers by the question 'What is the catchment?' Different qualities of water may become mixed and in the recent lively debate in Spain over the proposed water transfer from the Ebro to the Segura catchments, it has sometimes been forgotten that the Ebro waters are naturally saline at the proposed take-off point as a result of the contribution from the highly saline marls and evaporite rocks of the middle and lower part of the basin just east of Zaragoza.

The Segura River in Murcia illustrates all these issues. It has been transformed by human activity for over two 
millennia, from changes of land use in the Bronze Age to the recent water quality implications of the fruitprocessing industry in the towns along its course, that have resulted in a seriously polluted river. Many of the structural changes to its course were devised as a compromise between evacuating flood waters as fast as possible and encouraging aquifer recharge as much as possible. Significant areas of the catchment are severely eroded and there already exists a management plan to reduce erosion and its associated high runoff rates and sediment yield. The flooding problem is an important issue and dam construction is a major element in runoff control and flood protection.

The Water Framework Directive represents a crucial shift in thinking towards the principles of integrated catchment management. However, the practice of integrated catchment management is broader than the practice of integrated water management which has been a keystone for many years in the control of Mediterranean rivers. Guidelines cannot be too prescriptive, but must take account of the diversity of both environment and culture in Europe. At the same time they must be rigid enough to ensure compliance. The implementation of the Water Framework Directive is a very costly and demanding activity to impose on those catchments that are thinly populated or in economically marginal areas.

In closing this chapter we reiterate the point that it is impossible to understand the hydrology of Mediterranean catchments without appreciating the huge impact of human activities. On the other hand, nature is a strong force that cannot be ignored. Incursions into areas with a high flood risk, careless disregard for modifications of land use and exploitative use of groundwater all come at a high cost. Whilst it can be argued that the integrated approach of the Water Framework Directive in the dryland catchments of southern Europe would be inappropriate (Thornes and Rowntree 2006), it might yet yield important lessons for the integrated management of river catchments across the entire Mediterranean region.

\section{Acknowledgements}

The authors thank the external reviewer who provided valuable comments on an earlier draft of this chapter. Nick Scarle in the Cartographic Unit at The University of Manchester expertly redrafted the figures. We thank Ian Foster for providing photographs of Israel and Tunisia.

\section{References}

Beven, K. (2002), Run-off generation in semi-arid areas, in L. J. Bull and M. J. Kirkby (eds.), Dryland Rivers: Hydrology and Geomorphology of Semi-Arid Channels. John Wiley \& Sons, Chichester, 57-105.

Bochet, E., Poesen, J., and Rubio, J. L. (2006), Runoff and soil loss under individual plants of a semi-arid Mediterranean shrubland: influence of plant morphology and rainfall intensity. Earth Surface Processes and Landforms, 31/5: 536-50.

Borel, L. (1994), Influence des aménagements sur l'évolution des Milieux Durnciens-dynamique des peuplements vegetaux et animaux, in J. Riser (ed.), Aménagements et gestion des grandes rivières mediterranéennes. Étude Vauclusiennes 5: 15-19.

Brookes, A. and Shields, F. D. (2001), River Restoration. John Wiley \& Sons, Chichester.

Bull, L. J., Kirkby, M. J., Shannon, J., and Hooke, J. M. (2000), The impact of storms on floods in ephemeral channels in south-east Spain. Catena 38/3: 191-210.

Butcher, G. C. and Thornes, J. B. (1978), Spatial variability in runoff processes in an ephemeral channel. Zeitschrift für Geomorphologie Suppl. 29: 83-92.

Carson, M. A. and Kirkby, M. J. (1972), Hillslope Form and Process. Cambridge University Press, Cambridge.

Chirino, E., Bonet, A., Bellot, J., and Sanchez, J. R. (2006), Effects of 30 year old Allepo pine plantations on runoff, soil erosion and plant diversity in a semi-arid landscape in south-eastern Spain. Catena 31/1: 19-30.

Christopoulos, G. (1998), Late Holocene river behaviour in the lower Alfios basin, Western Greece. Ph.D. Thesis, University of Leeds.

Conesa-Garcia, C. and Alonso-Sarria, F. (1997), Stochastic matrices applied to the probabilistic analysis of runoff events in a semi-arid stream. Hydrological Processes 11: 297-310.

Cudennec, C., Leduc, C., and Koutsoyiannis, D. (2007), Dryland hydrology in Mediterranean regions-a review. Hydrological Sciences Journal 52: 1077-87.

Dedkov, A. P. and Moszherin, V. T. (1992), Erosion and sediment yield in mountain areas of the world, in D. E. Walling, T. R. Davies, and B. Hasholt (eds.), Erosion, Debris Flows and Environment in Mountain Regions of the World. IAHS Publication 209: 29-36.

Dunne, T. and Black R. D. (1970), Partial area contributions to storm runoff-producing zones in a small New England watershed. Water Resources Research 6: 1296-311.

Eagleson, P. S. (1978), Climate, soil and vegetation. 6. Dynamics of the annual water balance. Water Resources Research 14/5: 749-64.

Elwell, H. A. and Stocking, M. A. (1976), Vegetation cover to estimate soil erosion hazard in Rhodesia. Geoderma 15: $61-70$.

Evenari, M., Shanan, L., and Tadmor, N. (1982), The Negev: The Challenge of a Desert. Harvard University Press, Cambridge, Mass.

Francis, C. F. and Thornes, J. B. (1990), Runoff hydrographs from the Mediterranean vegetation cover types, in: J. B. Thornes (ed.), Vegetation and Erosion, John Wiley and Sons, Chichester, 313-84.

- (1994), Matorral: erosion and reclamation, in J. Albaladejo, M. A. Stocking, and E. Diaz (eds.), Soil Degradation and Rehabilitation in Mediterranean Environmental Conditions. Consejo Superior de Investigaciónes Científicas, Madrid, 87-116.

Garcia, C., Laronne, J. B., and Sala, M. (2000), Continuous monitoring of bedload flux in a mountain gravel-bed river. Geomorphology 34: 23-31. 
Garcia-Ortiz, E. (2006), Efecto de la structura de la copa en la partición de lluvia de tres species arbustivas en clima semiarido. Doctoral thesis, University of Almeria.

Gil Olcina, A. (1971), El Campo de Lorca: estudio de geografía agraria. CSIC, Valencia.

Gobster, P. H. and. Hull, R. B (eds.) (2000), Restoring Nature: Perspectives from the Social Sciences and Humanities. Island, Washington.

Gómez-Espin, J. M. (2004), Approvechamiente Integral del Agua en la Rambla de Nogalte (Puerta Lumbreras-Murcia), University of Murcia, Murcia.

Grenon, M. and Batisse, M. (eds.) (1989), Futures for the Mediterranean Basin: The Blue Plan. Oxford University Press, Oxford.

Grove, A. T. and Rackham, O. (2003), The Nature of Mediterranean Europe: An Ecological History. Yale University Press, New Haven.

Hull, R. B. and Robertson, D. P. (2000), The language of nature matters: we need more Public Ecology, In P. H. Gobster and R. B. Hull (eds.), Restoring Nature: Perspectives from the Social Sciences and Humanities. Island, Washington.

Imeson, A. C., Verstraten, E. J., Mulligan, J. M., and Sevink, J. (1992), The effects of fire and water repellency on infiltration and runoff under Mediterranean type forest. Catena 19 345-61.

Inbar, M. (1992), Rates of fluvial erosion in basins with a Mediterranean type climate. Catena 19: 393-409.

Laronne, J. B. and Reid, I. (1993), Very high rates of bedload sediment transport by ephemeral desert rivers. Nature 366 : 148-50.

Kapsimalis, V., Poulos, S. E., Karageorgis, A. P., Pavlakis, P., and Collins, M. (2005), Recent evolution of a Mediterranean deltaic coastal zone: human impacts on the Inner Thermaikos Gulf, NW Aegean Sea. Journal of the Geological Society, London 162: 879-908.

Kirkby, M. J. (1969), Infiltration, throughflow and overland flow, In R. J. Chorley (ed.), Water, Earth and Man. Methuen, London, 215-28.

Bracken, L., and Reaney, S. (2002), The influence of land use, soils and topography on the delivery of hillslope runoff to channels in SE Spain. Earth Surface Processes and Landforms 27: 1459-73.

Lahlou, A. (1988), The silting of Moroccan dams, in M. P. Bordas and D. E. Walling (eds.), Sediment Budgets. IAHS Publication 174: $71-7$.

Lange, J., Leibundgut, C., Greenbaum, N., and Schick, A. P. (1999), A non-calibrated rainfall-runoff model for large arid catchments. Water Resources Research 35: 2161-72.

Lewin, J., Macklin, M. G., and Woodward, J. C. (eds.) (1995), Mediterranean Quaternary River Environments. Balkema, Rotterdam.

Macklin, M.G., Lewin, J., and Woodward, J. C. (1995), Quaternary fluvial systems in the Mediterranean basin, in J. Lewin, M. G. Macklin, and J. C. Woodward (eds.), Mediterranean Quaternary River Environments. Balkema, Rotterdam, $1-25$.

McNeill, J. R. (1992), The Mountains of the Mediterranean World. Cambridge University Press, Cambridge.

Mavromati, E. and Chryssaidis, L. (2007), Aqueducts in the Hellenic area during the Roman Period. Water Science and Technology: Water Supply 7: 139-45.

Nicholas, A. P., Woodward, J. C., Christopoulos, G., and Macklin, M. G. (1999), Modelling and monitoring the impact of dam construction and gravel extraction on rates of bank erosion in the Alfios River, Peloponnese, western Greece, in A. G. Brown and T. A. Quine (eds.) Fluvial Processes and Environmental Change. John Wiley \& Sons, Chichester, $117-37$.

Obando, J. (2002), The impact of land abandonment on regeneration of semi-natural vegetation. A case study from the Guadalentin, in J. A. Geeson, C. J. Brandt, and J. B. Thornes, Mediterranean Desertification: A Mosaic of Processes and Responses. John Wiley \& Sons, Chichester, 269-77.

Pocklington, R. (1986), Acequias árabes y pre-árabes en Murcia y Lorca: apportación toponímica a la historia del regadío, in $X$ Colloqui General de la Societat d'Onomàstica, 1985. University of Valencia, 462-73.

Probst, J. L., and Amiotte Suchet, P. (1992), Fluvial suspended sediment transport and Mechanical erosion in the Maghreb (North Africa). Hydrological Sciences Journal 37: $621-37$.

Reid, I. and Laronne, J. B. (1995), Bedload sediment transport rates in an ephemeral stream and a comparison with seasonal and perennial counterparts. Water Resources Research 31: $773-81$.

— and Powell, D. M. (1998), Flash-flood and bedload dynamics of desert gravel-bed streams. Hydrological Processes 12: 543-57.

Rojo Serrano, L., Garcia Robredo, F., Martinez Artero, J. A., and Martinez Ruiz, A. (2002), Management Plan to combat desertification in the Guadalentin River Basin, in N. A. Geeson, C. J. Brandt, and J. B. Thornes (eds.), Mediterranean Desertification: A Mosaic of Processes and Responses. John Wiley \& Sons, Chichester, 303-19.

Rovira, A., Batalla, R. J., and Sala, M. (2005), Fluvial sediment budget of a Mediterranean river: the lower Tordera (Catalan Coastal Ranges, NE Spain). Catena 60: 19-42.

Shannon, J., Richardson, R., and Thornes, J. B. (2002), Modelling event-based fluxes in ephemeral streams in L. J. Bull and M. J. Kirkby (eds.), Dryland Rivers: Hydrology and Geomorphology of Semi-Arid Channels. John Wiley and Sons, Chichester, 129-72.

Struglia, M. V., Mariotti, A., and Filograsso, A. (2004), River discharge into the Mediterranean Sea: climatology and aspects of the observed variability. Journal of Climate 17: 4740-51.

Syvitski, J. P. M., Vörösmarty, C. J., Kettner, A. J., and Green, P. (2005), Impact of humans on the flux of terrestrial sediment to the global coastal ocean. Science 308: 376-80.

Thornes, J. B. (1977), Channel changes in ephemeral streams: observations, problems and models, in K. J. Gregory (ed.), River Channel Changes. John Wiley \& Sons, Chichester.

(2007), Modelling soil erosion by grazing: recent developments and new approaches. Australian Geographical Research 45: 13-26.

- and Rowntree, K. (2006), Integrated catchment management in semi-arid environments in the context of the European Water Framework Directive. Land Degradation and Development 17: 255-264.

Victoria Jumilla, F. and Vicente Lopez, E. (1986), La contaminación de las aguas en la region de Murcia. Ministerio de Obras Publicas, Murcia.

Vita-Finzi, C. (1978), Archaeological Sites in their Setting. Thames \& Hudson, London.

Wainwright, J. (1996), Infiltration, runoff and erosion characteristics of agricultural land in extreme storm events, S. E. France. Catena 26: 27-47. 
- and Thornes, J. B. (2003), Environmental Issues in the Mediterranean: Processes and Perspectives from the Past and Present. Routledge, New York.

Walling, D. E. (1984), The sediment yields of African rivers, in

D. E. Walling, S. S. D. Foster, and P. Wurzel (eds.), Challenges in African Hydrology and Water Resources. IAHS Publication 144: 265-83.

Woodward, J. C. (1995), Patterns of erosion and suspended sediment yield in Mediterranean river basins, in I. D. L. Foster,

A. M. Gurnell, and B. W. Webb (eds.), Sediment and Water
Quality in River Catchments. John Wiley \& Sons, Chichester, 365-89.

- and Foster, I. D. L. (1997), Erosion and suspended sediment transfer in river catchments: environmental controls, processes and problems. Geography 82/4: 353-76.

- Macklin, G., Krom, M. D., and Williams, M. A. J. (2007), The Nile: evolution, Ouaternary river environments and material fluxes, in A. Gupta (ed.), Large Rivers: Geomorphology and Management. John Wiley \& Sons, Chichester, 261-92.

\section{This chapter should be cited as follows}

Thornes, J. B., López-Bermúdez, F., and Woodward, J. C. (2009), Hydrology, river regimes, and sediment yield, in J. C. Woodward (ed.), The Physical Geography of the Mediterranean. Oxford University Press, Oxford, 229-253. 
08-Woodward-C08 9780199268030-Jamie-Woodward (Typeset by SPi, Chennai) 254 of 254 April 15, 2009 12:40 